\title{
ROS-Induced Activation of DNA Damage Responses Drives Senescence-Like State in Postmitotic Cochlear Cells: Implication for Hearing Preservation
}

\author{
Nesrine Benkafadar ${ }^{1,2} \cdot$ Florence François $^{1,2} \cdot$ Corentin Affortit $^{1,2} \cdot$ François Casas $^{3}$ • Jean-Charles Ceccato ${ }^{1,2}$. \\ Julien Menardo $^{1,2} \cdot$ Frederic Venail $^{1,2} \cdot$ Bernard Malfroy-Camine $^{4} \cdot$ Jean-Luc Puel ${ }^{1,2} \cdot$ Jing Wang $^{1,2}$
}

Received: 28 August 2018 / Accepted: 11 January 2019 /Published online: 28 January 2019

(C) The Author(s) 2019

\begin{abstract}
In our aging society, age-related hearing loss (ARHL) has become a major socioeconomic issue. Reactive oxygen species (ROS) may be one of the main causal factors of age-related cochlear cell degeneration. We examined whether ROS-induced DNA damage response drives cochlear cell senescence and contributes to ARHL from the cellular up to the system level. Our results revealed that sublethal concentrations of hydrogen peroxide $\left(\mathrm{H}_{2} \mathrm{O}_{2}\right)$ exposure initiated a DNA damage response illustrated by increased $\gamma \mathrm{H} 2 \mathrm{AX}$ and 53BP1 expression and foci formation mainly in sensory hair cells, together with increased levels of pChk2 and p53. Interestingly, postmitotic cochlear cells exposed to $\mathrm{H}_{2} \mathrm{O}_{2}$ displayed key hallmarks of senescent cells, including dramatically increased levels of p21, p38, and p-p38 expression, concomitant with decreased p19 and BubR1 expression and positive senescence-associated $\beta$-galactosidase labeling. Importantly, the synthetic superoxide dismutase/catalase mimetic EUK207 attenuated $\mathrm{H}_{2} \mathrm{O}_{2}$-induced DNA damage and senescence phenotypes in cochlear cells in vitro. Furthermore, systemic administration of EUK-207 reduced age-related loss of hearing and hair cell degeneration in senescence-accelerated mouse-prone 8 (SAMP8) mice. Altogether, these findings highlight that ROS-induced DNA damage responses drive cochlear cell senescence and contribute to accelerated ARHL. EUK-207 and likely other antioxidants with similar mechanisms of action could potentially postpone cochlear aging and prevent ARHL in humans.
\end{abstract}

Keywords Oxidative stress $\cdot$ DNA damage responses $\cdot$ Senescence $\cdot$ Age-related hearing loss $\cdot$ Hearing preservation

\section{Introduction}

Age-related hearing loss (ARHL) or presbycusis is the third most prevalent chronic disease among older adults [1]. It can vary in severity from mild to severe, the more severe forms affecting communication and contributing to social isolation, depression, and possibly dementia [2]. There is general agreement that cumulative effects of aging on hearing are exacerbated by genetic predisposition and environmental

Jing Wang

jing.wang@inserm.fr

1 INSERM - UMR 1051, Institut des Neurosciences de Montpellier, 80 rue Augustin Fliche, 34295 Montpellier, France

2 Université Montpellier, 34295 Montpellier, France

3 INRA, UMR 866 Différenciation Cellulaire et Croissance, 34060 Montpellier, France

4 MindSet Rx, Arlington, MA, USA factors such as noise or drug exposure. With increasing noise pollution and life expectancy in our modern society, the prevalence of presbycusis is expected to grow dramatically. The precise mechanisms behind the age-related degeneration of the cochlear structures remain unclear, however. This is in part due to the complexity of each causal factor and to the interaction of the different mechanistic pathways leading to ARHL.

Growing evidence links oxidative stress to ARHL [3, 4]. The presence of lipid peroxidation [4], oxidative mitochondrial DNA damage, and glutathione-conjugated proteins $[5,6]$ is each strongly associated with cochlear aging in mice. In addition, reduced expression of antioxidant enzymes such as catalase, mitochondrial manganese superoxide dismutase (MnSOD or SOD2), and cytosolic SOD1 has been observed in older mice [4-6]. Furthermore, mice lacking the antioxidant enzyme SOD1 display enhanced age-related cochlear hair cell loss, reduced thickness of the stria vascularis, and severe degeneration of spiral ganglion neurons (SGNs) [7]. On the 
other hand, an increase in SOD2 expression gradient in ganglion cells has been reported along the basal to apical axis of rodent and primate cochlea [8], consistent with the differential vulnerability of the varying areas in the cochlea, from the most vulnerable high-frequency to least vulnerable low-frequency regions in most ARHL. Finally, low serum levels of the ROS scavenger melatonin are significantly associated with the occurrence of highfrequency hearing loss in the elderly [9]. Taken together, this experimental and clinical evidence indicates the potential involvement of oxidative stress in ARHL.

It is generally accepted that oxidative stress may cause irreversible DNA damage [10]. Over 100 oxidative modifications to DNA have been identified, including adducts and both single-strand and double-strand breaks [11]. In the cochlea, we have recently reported the activation of the DNA damage response (DDR) in postmitotic inner ear cells following treatment with the ototoxic anticancer drug cisplatin [12]. However, the link between increased ROS, DNA damage, and cochlear cell aging remains obscure. Understanding ROS-induced cochlear cell degeneration may lead to identifying key molecular targets to protect residual hearing in patients suffering ARHL.

The synthetic superoxide dismutase (SOD)/catalase mimetic EUK-207 is a member of the class of metal-containing salen-manganese (Mn) complexes. EUK-207 suppresses oxidative stress, including in the mitochondria [13, 14], through transforming oxygen free radicals into oxygen via a superoxide dismutase-like activity, and hydrogen peroxide into oxygen and water by a catalase-like activity [13]. EUK-207 has been used successfully to suppress age-related $[15,16]$ and radiation-induced cognitive impairment in mice [17].

Here, we explore the hypothesis that ROS-induced DDR drive cochlear cell senescence and contribute to ARHL from the cellular to the system level. In our in vitro study, hydrogen peroxide $\left(\mathrm{H}_{2} \mathrm{O}_{2}\right)$ exposure caused DNA damage and initiated a DNA damage response in cochlear cells, as demonstrated by activation of the Chk2-p53 pathway. In addition, the $\mathrm{H}_{2} \mathrm{O}_{2}-$ exposed cochlear cells exhibited several additional senescence-associated properties, including high senescenceassociated $\beta$-galactosidase activity mainly in sensory hair cells, together with massively increased levels of p21, p38, and $\mathrm{p}$-p38. Our in vivo results from senescence-accelerated mouse-prone 8 (SAMP8) mice, the well-characterized model of premature cochlear aging [4], demonstrated a similar accumulation of high amounts of DNA damage and similar senescence-like features in the cochlear tissues during aging. Importantly, EUK-207 attenuated $\mathrm{H}_{2} \mathrm{O}_{2}$-induced DNA damage and senescence phenotype in cochlear cells in vitro and reduced age-related loss of both hearing and hair cells in SAMP8 mice. These results highlight the attractive potential of antioxidants as a tool with which ARHL could be slowed down.

\section{Material and Methods}

\section{Animals}

Neonate Swiss mice were purchased from Janvier Laboratories. The senescence-accelerated mouse strain is derived from $\mathrm{AKR} / \mathrm{J}$ mice by continuous brother-sister mating selected for a phenotype toward either accelerated senescence (SAMP) or resistance senescence (SAMR) [18]. Among these strains, SAMP8 mice have strain-specific characteristics of rapid aging [19]. Here, SAMP8 and senescence-accelerated mouse-resistant 1 (SAMR1) of both sexes were purchased from Harlan SARL Laboratory. Mice were housed in pathogen-free animal care facilities accredited by the French Ministry of Agriculture and Forestry (C-34-172-36; December 19, 2014).

\section{Drug Preparation}

$\mathrm{H}_{2} \mathrm{O}_{2}$ was purchased from Acros Organics (\#202460250). The salen-manganese (Mn) SOD-catalase mimetic, EUK207, was a gift from Dr. Bernard Malfroy-Camine, of MindSet Rx, Arlington, MA, USA.

For in vitro experiments, $\mathrm{H}_{2} \mathrm{O}_{2}$ was freshly prepared in culture medium to final concentrations ranging from 0 to $1.25 \mathrm{mM}$. The EUK-207 was prepared at $10 \mathrm{mM}$ in pure water and freshly diluted in culture medium to a final concentration of $10 \mu \mathrm{M}$. This final concentration was chosen based on our preliminary evaluations of the dose-response effects of EUK207, at concentrations ranging from 0 to $30 \mu \mathrm{M}$, on $\mathrm{H}_{2} \mathrm{O}_{2}$ induced $\gamma \mathrm{H} 2 \mathrm{AX}$ expression on day 3 in $\mathrm{H}_{2} \mathrm{O}_{2}$-exposed cochlear explants. For in vivo experiments, EUK-207 was freshly prepared at $1.5 \mathrm{mM}$ in 5\% mannitol and was administered through a subcutaneously implanted Alzet micro-osmotic pump (DURECT Corporation, $0.11 \mu \mathrm{l}$ per hour, 28 days \#1004) at a dose of $0.2 \mathrm{mg} / \mathrm{kg} /$ day.

\section{In Vitro Assessments}

\section{Organ of Corti and Whole Cochlea Cultures}

Mouse whole cochleae and organ of Corti explants were collected from postnatal day 3 mice and prepared according to the procedures described previously $[12,20]$. The whole cochleae were kept in suspension, and the organ of Corti explants in adherent conditions in a 6-well culture plate containing $2 \mathrm{ml} /$ well of culture medium. Culture medium consisted of Dulbecco's modified Eagle's medium/nutrient mixture F-12 (DMEM/F-12, \#21331020) containing $2 \mathrm{mM}$ L-glutamine (\#25030024), N-2 complement (\#17502048) at $1 \times$ and insulin transferrin selenium (\#41400045) at $1 \times$ purchased from Gibco Life technologies, and $8.25 \mathrm{mM}$ D-glucose (\#G6152) and $30 \mathrm{U} / \mathrm{ml}$ penicillin G (\#P3032) from Sigma-Aldrich. 


\section{$\mathrm{H}_{2} \mathrm{O}_{2}$-Induced Oxidative Stress}

The oxidizing agent used to induce oxidative stress in vitro $\left(\mathrm{H}_{2} \mathrm{O}_{2}\right)$ was chosen based on its wide use in a variety of cell types [21, 22]. Here, cochlear samples were firstly exposed to culture medium alone for $24 \mathrm{~h}$ in a humidified incubator $\left(37^{\circ} \mathrm{C}, 5 \% \mathrm{CO}_{2}\right)$. To probe the dose effect of $\mathrm{H}_{2} \mathrm{O}_{2}$, the culture medium was then replaced with fresh medium containing $\mathrm{H}_{2} \mathrm{O}_{2}$ at various concentrations $(0,0.25,0.4,0.5,0.75,1$, and $1.25 \mathrm{mM}$ ) for $5 \mathrm{~h}$ before being replaced again with the culture medium alone and maintained for 5 days. The culture medium was renewed once on day 2 or 3 following its replacement. To determine time-dependent cochlear cell degeneration, organ of Corti explants were exposed to medium containing $\mathrm{H}_{2} \mathrm{O}_{2}$ at its half maximal effective concentration $\left(\mathrm{EC}_{50}\right)$ and also at the concentration just below the $\mathrm{EC}_{50}$ $(0.5 \mathrm{mM})$ for $5 \mathrm{~h}$ and then maintained in the culture medium alone for $0,1,3$, and 5 days. All control samples were maintained in culture medium alone and were run concurrently alongside the experimental cultures.

\section{Dose-Dependent Cytotoxicity and Apoptosis}

To evaluate the toxicity of $\mathrm{H}_{2} \mathrm{O}_{2}$, cultured organ of Corti explants were immunolabeled with a rabbit polyclonal antibody against myosin 7A (1/300, Proteus Biosciences Inc. \#256790 ) and a mouse monoclonal antibody against neurofilament (NF 200, 1/600, Sigma-Aldrich \#N0142) to label hair cells and spiral ganglion neurons, respectively. Hair cell counting (six cochleae per condition and per time point) was performed using standard techniques [20]. Due to the resistance of apical turn hair cells to $\mathrm{H}_{2} \mathrm{O}_{2}$ cytotoxicity, counting concerned only a $1.5-\mathrm{mm}$ length of the cochlear duct at the basal turn (4 to $5.5 \mathrm{~mm}$ from the apex, see [12]).

The TUNEL kit (DeadEnd ${ }^{\mathrm{TM}}$ fluorometric TUNEL System, Promega \#G3250) was used to identify apoptotic DNA fragmentation. The cochlear samples were counterstained with a rabbit polyclonal antibody against myosin $7 \mathrm{~A}$ and a mouse monoclonal antibody against neurofilament. All secondary antibodies were used at a dilution of $1 / 1000$. This included donkey anti-mouse and anti-rabbit IgG conjugated to Alexa 488 or Alexa 568 (Molecular Probes \#A-21202, \#A21206, \#A-10037, \#A-10042). Fluorescent tags were visualized using a confocal microscope (LSM 5 Live Duo, Zeiss). In control specimens without primary antibodies, neither Alexa 488 nor 568 fluorescent tags were observed. All experiments were performed in triplicate.

\section{Measurement of Oxidative Stress}

Oxidative stress was studied in the whole cochlea homogenates as previously described [4]. Catalase and SOD activities were measured as previously described by Marklund [23].
Lipid peroxidation was assessed using the thiobarbituric acid-reactive substances method and was expressed in nanomoles per milligram malondialdehyde (MDA) [24]. Protein concentrations were measured using the $\mathrm{BCA}$ protein assay kit (Pierce \#23250). All experiments were performed in triplicate.

\section{Cellular Localization of DNA Damage Foci and Foci Counting}

Immunocytochemistry was employed to localize DNA damage foci in cultured organ of Corti using mouse monoclonal antibody against phospho-H2AX (1/500, Ser139, Merck Millipore \#05-636) or rabbit polyclonal antibody against 53BP1 (1/100, Novus Biologicals \#NB100-305). The cochlear samples were counterstained with a rabbit polyclonal antibody against myosin $7 \mathrm{~A}$ or mouse monoclonal antibody against parvalbumin $(1 / 500$, SWANT \#PV235) to label hair cells. All secondary antibodies were used at a dilution of 1/1000. The Hoechst 33342 dye (0.002\% wt:vol in PBS 1×, Thermo Fisher Scientific \#62249) was used to stain DNA. Fluorescent tags were visualized using a confocal microscope (LSM 5 Live Duo, Zeiss). No fluorescent signal was detected in the control specimens without primary antibodies.

The number of foci (i.e., $\gamma \mathrm{H} 2 \mathrm{AX}$ or 53BP1) per nucleus was computed using algorithms with Matlab custom-made software (MathWorks Company) that allow 3D rendering and visualization of "isosurfaces" enveloping all pixel clusters with intensities greater than a user-defined criterion value in each corresponding image channel (for more details, see [12]). All experiments were performed in triplicate.

\section{Expression of Apoptosis, Oxidative Stress, and Autophagy-Related Proteins, DNA Damage Response, and Senescence Markers}

Evaluation of apoptosis, oxidative stress, autophagy, DNA damage responses, and cellular senescence-like state in the cochlear protein extracts from $\mathrm{H}_{2} \mathrm{O}_{2}$-exposed and cultured whole cochleae was performed using Western blotting technique as described previously [4]. Antibodies used included those recognizing Bax (1/1000, Abcam \#7977), BCl2 (1/1000, Santa Cruz \#sc-492), cleaved caspase 3 (1/1000, Asp175 Cell Signaling \#9661), SOD2 (1/1000, Abcam \#ab13533), catalase (1/1000, Abcam \#16731), p66 ${ }^{\text {Shc }}$ (1/1000, Abcam \#ab33770), phospho- p66 ${ }^{\text {Shc }}$ (S36, 1/1000, Abcam \#54518), p-Beclin 1 Ser93 (1/1000, Cell Signaling \#14717), LC3-II (1/800, Cell Signaling \#2775), Rab7 (1/800, Santa Cruz Biotechnology \#sc-376,362), p62 (1/1000, MBL International \#PM045), phospho-H2AX (1/1500, Ser139, Cell Signaling \#2577), 53BP1 (1/1000, Novus Biologicals \#100-305), DDB2 (1/800, Invitrogen \#PA5-37361), phospho-Chk1 (1/1000, Ser345, Cell Signaling \#2348), phospho-Chk2 (1/1000, Thr68, Cell 
Signaling \#2661), p53 (1/1500, Cell Signaling \#2524), p21 (1/2000, Cell Signaling \#2946), p38 (1/500, Elabscience \#EAB-32459), p-p38 (Thr180/Tyr182, 1/1000, Cell Signaling \#9211), p16 (1/1000, BD Pharmingen \#551154), p19 (1/1000, Abcam \#ab80), BubR1 (1/1000, Abcam \#ab183496), FOXO3a (1/1000, Cell Signaling \#2497), and nuclear factor erythroid 2-related factor 2 (Nrf2) (1/1000, Santa Cruz \# sc-365949). $\beta$-Actin (1/10,000, Sigma-Aldrich \#A1978) served as a loading control. Secondary antibodies used were horseradish peroxidase-conjugated goat antimouse IgG antibodies (1/3000, Jackson ImmunoResearch \#115-001-003) or goat anti-rabbit IgG antibodies (1/3000, Jackson ImmunoResearch \#111-001-003). All experiments were performed in triplicate. Image scans of Western blots were used for semiquantitative analysis.

\section{Senescence-Associated Beta-Galactosidase Activity Assay}

Senescence-associated beta-galactosidase (SA- $\beta$-gal) activity was measured according to the manufacturer's protocol (Cell Signaling \#9860). Briefly, cultured cochlear explants and cochleae from 6-month-old SAMR1 and SAMP8 mice were fixed in $4 \%$ paraformaldehyde in phosphate-buffered saline $1 \times(\mathrm{PBS})$ for $30 \mathrm{~min}$ at room temperature and washed twice with PBS. The fixed SAMR1 and SAMP8 cochleae were then processed for either cryosectioning or surface preparation. All cochlear samples were then incubated overnight at $37^{\circ} \mathrm{C}$ in a dry incubator with fresh $\beta$-galactosidase staining solution at pH 6.0. Cochlear explants were observed using light microscopy, while cryosections and surface preparations were scanned using a NanoZoomer (Hamamatsu Photonics, Hamamatsu City, Japan) with a $\times 40$ objective.

\section{Pharmacological Mitigation of ROS}

To probe the impact of ROS mitigation on $\mathrm{H}_{2} \mathrm{O}_{2}$-induced DNA damage and senescence-like phenotype, whole cochleae were exposed to either culture medium alone or medium containing $10 \mu \mathrm{M}$ EUK-207 for $24 \mathrm{~h}$ in a humidified incubator $\left(37{ }^{\circ} \mathrm{C}, 5 \% \mathrm{CO}_{2}\right)$. The culture medium was then replaced with fresh medium containing $\mathrm{H}_{2} \mathrm{O}_{2}$ at a concentration of $0.5 \mathrm{mM}$ for $5 \mathrm{~h}$. The cochlear samples were further grown for three additional days in culture medium either alone or with EUK207. All control samples were maintained in culture medium and were run concurrently with experimental cultures. The samples were then collected for the evaluation of oxidative stress, DNA damage, and cellular senescence-like state using Western blotting and immunolabeling techniques.

\section{Validation in Adult SAMP8 In Vivo}

Our previous study demonstrated that SAMP8 mice displayed premature ARHL and early onset cochlear cell degeneration when compared with the normally aging control senescenceaccelerated mouse-resistant 1 (SAMR1) mice [4].

\section{Functional Assessment}

The auditory function was assessed by recording auditory brainstem responses (ABRs) in SAMP8 and SAMR1 mice at the age of $1,3,6$, and 12 months $(n=14$ animals per age and per strain). ABRs reflect the synchronous activation of auditory neurons from the cochleae up to the colliculi in response to incoming sound. The recordings were carried out under anesthesia with Rompun $2 \%(3 \mathrm{mg} / \mathrm{kg})$ and Zoletil 50 $(40 \mathrm{mg} / \mathrm{kg})$ in a Faraday-shielded anechoic soundproof cage. Rectal temperature was measured with a thermistor probe and maintained at $38.5 \pm 1{ }^{\circ} \mathrm{C}$ using a heated under blanket. ABRs were recorded from three subcutaneous needle electrodes placed at the vertex (active) and on the pinna of the tested ear, as well as in the neck muscles (ground) of the mice. The acoustic stimuli generated by a NI PXI-4461 signal generator (National Instruments) consisted of $10 \mathrm{~ms}$ tone bursts with a $1-\mathrm{ms}$ rise and fall time delivered at a rate of $10 / \mathrm{s}$. Sound was delivered by a JBL 075 loudspeaker (James B. Lansing Sound) positioned at $10 \mathrm{~cm}$ from the tested ear, under calibrated free-field conditions. Cochlear amplification $(20,000)$ was achieved via a Grass P511 differential amplifier, averaged 1000 times (Dell Dimensions). Amplitude-intensity functions of the ABRs were obtained at each frequency tested $(2,4,6.3$, $8,10,12.5,16,20,25$, and $32 \mathrm{kHz}$ ) by varying the intensity of the tone bursts from 0 to $100 \mathrm{~dB}$ SPL, in $5 \mathrm{~dB}$ incremental steps. The ABR thresholds were defined as the minimum sound intensity necessary to elicit a well-defined and reproducible wave II. Recordings and analysis were performed blindly.

\section{Molecular Assessment}

Evaluation of oxidative stress, DNA damage responses, and cellular senescence-like state in the cochlear protein extracts from the cochleae of SAMP8 and SAMR1 mice aged 1, 6, and 12 months ( $n=16$ cochleae per age and per strain) was performed using Western blotting technique as described previously [4]. Antibodies used included those recognizing Nrf2 (1/1000, Santa Cruz \#sc-365949), SOD2 (1/1000, Abcam \#ab13533), p66 ${ }^{\text {Shc }}$ (1/1000, Abcam \#ab33770), phosphop66 ${ }^{\text {Shc }}$ (S36, 1/1000, Abcam \#54518), phospho-Chk2 (1/1000, Thr68, Cell Signaling \#2661), p53 (1/1500, Cell Signaling \#2524), phospho-p53 (1/1500, Ser15, Cell Signaling \#9289), p21 (1/2000, Cell Signaling \#2946), p16 (1/1000, BD Pharmingen \#551154), BubR1 (1/1000, Abcam \#ab183496), and p19 (1/1000, Abcam \#ab80). $\beta$-Actin (1/10,000, Sigma-Aldrich \#A1978) served as a loading control. Secondary antibodies used were horseradish peroxidaseconjugated goat anti-mouse IgG antibodies (1/3000, Jackson 
ImmunoResearch \#115-001-003) or goat anti-rabbit IgG antibodies (1/3000, Jackson ImmunoResearch \#111-001-003). All experiments were performed in triplicate. Image scans of Western blots were used for semiquantitative analysis.

\section{Age-Related Hearing Impairment and Molecular Correlation}

To compare the time course of the hearing impairments found in SAMP8 and SAMR1 mice, the mean ABR threshold evoked by the range of tested frequencies from 2 to $32 \mathrm{kHz}$ for each strain and at each time point was calculated. A linear regression was then performed to determine the threshold elevation per month. To decipher the molecular determinants of the accelerated age-related hearing impairment in SAMP8 mice, we used the mean values of ABR thresholds and protein levels in SAMR1 as a reference and subtracted these from the values for SAMP8 mice. The differences in threshold and protein level (SAMP8 - mean SAMR1) were then averaged and used for statistical analysis and to calculate SEM.

\section{Pharmacological Counteraction of ROS}

Finally, the impact of ROS mitigation on premature ARHL was also investigated in SAMP8 mice. The 6-month-old male and female SAMP8 mice were randomly divided into two groups: (i) control 5\% mannitol (vehicle, $n=10$ ) and (ii) EUK-207 $(n=10)$. The EUK-207 was dissolved in 5\% mannitol to a final concentration of $1.5 \mathrm{mM}$, filter-sterilized, and administered at a dose of $0.2 \mathrm{mg} / \mathrm{kg} /$ day with the use of a subcutaneous Alzet micro-osmotic pump, continuing for up to 84 days. This dose of EUK-207 was selected according to the effective EUK-207 dose range reported previously [16]. Control mice received pumps filled with $5 \%$ mannitol. Mice received new pumps every month.

The ABRs were recorded prior to pump implantation and 2 and 3 months afterwards. Sensory hair cell loss was evaluated using scanning electron microscopy (Hitachi S4000). The cochleae from the different groups ( $n=7$ per group) were processed and evaluated using previously reported standard techniques $[25,26]$. Hair cell counting was performed in four different $300-\mu \mathrm{m}$-long segments of the organ of Corti, centered at $1.1,2.6,3.5$, or $4.1 \mathrm{~mm}$ from the cochlear apical end and corresponding to the frequencies of $8,16,25$, and $32 \mathrm{kHz}$, respectively [27].

\section{Statistics}

Data are expressed as mean \pm SEM. Normality of the variables was tested by the Shapiro-Wilks test. The significance of the group differences was assessed with a one-way ANOVA; once the significance of the group differences $(P<0.05)$ was established, Tukey's post hoc tests were subsequently used for pairwise comparisons. Significance of linear regressions was determined using the Pearson correlation coefficient $(P<0.001)$. For in vivo mouse studies, based on data from our previous reports $[28,29]$ or from preliminary experiments, we calculated the sample size using $G^{*}$ Power 3.1.9.2 to ensure adequate power of key experiments for detecting prespecified effect sizes.

\section{Results}

\section{In Vitro Studies}

To probe a direct causal relationship between increased ROS and premature occurrence of cochlear cell senescence-like phenotype, we adapted an available in vitro model of oxidative stress [30, 31], which consists of exposing cochlear explants or whole cochleae to a series of $\mathrm{H}_{2} \mathrm{O}_{2}$ concentrations in culture.

\section{$\mathrm{H}_{2} \mathrm{O}_{2}$ Induces Dose-Dependent Outer Hair Cell Apoptosis}

We firstly determined the survival of cochlear cells under increasing concentrations of $\mathrm{H}_{2} \mathrm{O}_{2}$. Our results show that a 5-h exposure to $\mathrm{H}_{2} \mathrm{O}_{2}$ in the millimolar range led to a significant concentration-dependent loss of outer hair cells (OHCs) (loss of $\mathrm{OHCs}-0.5 \mathrm{mM}$ of $\mathrm{H}_{2} \mathrm{O}_{2}: \mathrm{F} 1: 22=14.2, P<0.001$; 0.75 mM: F1:34 =986, $P<0.001 ; 1 \mathrm{mM}: \mathrm{F} 1: 27=552, P<$ $0.001 ; 1.25 \mathrm{mM}$ : F1:34 $=884, P<0.001)$ in the basal turn of the organ of Corti 5 days later, in contrast to an only slight loss of inner hair cells (IHCs) (loss of IHCs-1 mM: F1:20 = 13.72, $P=0.002 ; 1.25 \mathrm{mM}: \mathrm{F} 1: 27=41.93, P<0.001)$ (Fig. 1a-e). A concentration of $1.25 \mathrm{mM}$ provoked $77 \%$ of OHC and $20 \%$ of IHC loss (Fig. 1e). The counting of hair cells remaining after exposure to $0.75 \mathrm{mM} \mathrm{H}_{2} \mathrm{O}_{2}\left(\mathrm{EC}_{50}\right)$ and $0.5 \mathrm{mM}$ (the concentration just below $\mathrm{EC}_{50}$ ) revealed a timedependent $\mathrm{OHC}$ loss. Indeed, a concentration of $0.75 \mathrm{mM}$ $\mathrm{H}_{2} \mathrm{O}_{2}$ led to a loss of $22.8 \pm 1.4$ and $50.2 \pm 1.52 \%$ OHCs at 3 and 5 days after exposure, respectively ( 3 days: $\mathrm{F} 1: 34=14.2$, $P<0.001,5$ days: $\mathrm{F} 1: 34=986, P<0.001$ ) (Fig. 1f), while $0.5 \mathrm{mM}$ provoked a respective loss of only $11.6 \pm 2$ and $28.4 \pm 4.7 \%$. In contrast, IHCs showed only slight alterations up to 5 days after exposure at all concentrations. We therefore performed all molecular assessments within 3 days after $\mathrm{H}_{2} \mathrm{O}_{2}$ exposure.

To determine the nature of the $\mathrm{H}_{2} \mathrm{O}_{2}$-induced hair cell loss, we probed for apoptotic markers at 3 days after $\mathrm{H}_{2} \mathrm{O}_{2}$ exposure. Large amounts of OHCs and some IHCs displayed TUNEL-positive nuclei (Fig. 1i, j) after incubation with the higher $\mathrm{H}_{2} \mathrm{O}_{2}$ concentration $(\geq 0.75 \mathrm{mM})$, when compared with controls or the sublethal concentration $(0.5 \mathrm{mM}$, Fig. $1 \mathrm{~g}, \mathrm{~h})$. Concomitantly, Western blots from protein extracts of $\mathrm{H}_{2} \mathrm{O}_{2}$ exposed cochleae showed significant caspase 3 activation in the cochleae exposed to $\geq 0.5 \mathrm{mM}$ of $\mathrm{H}_{2} \mathrm{O}_{2}($ Fig. $1 \mathrm{k}, 1)$ 


\section{Cytotoxic effect of hydrogen peroxide}
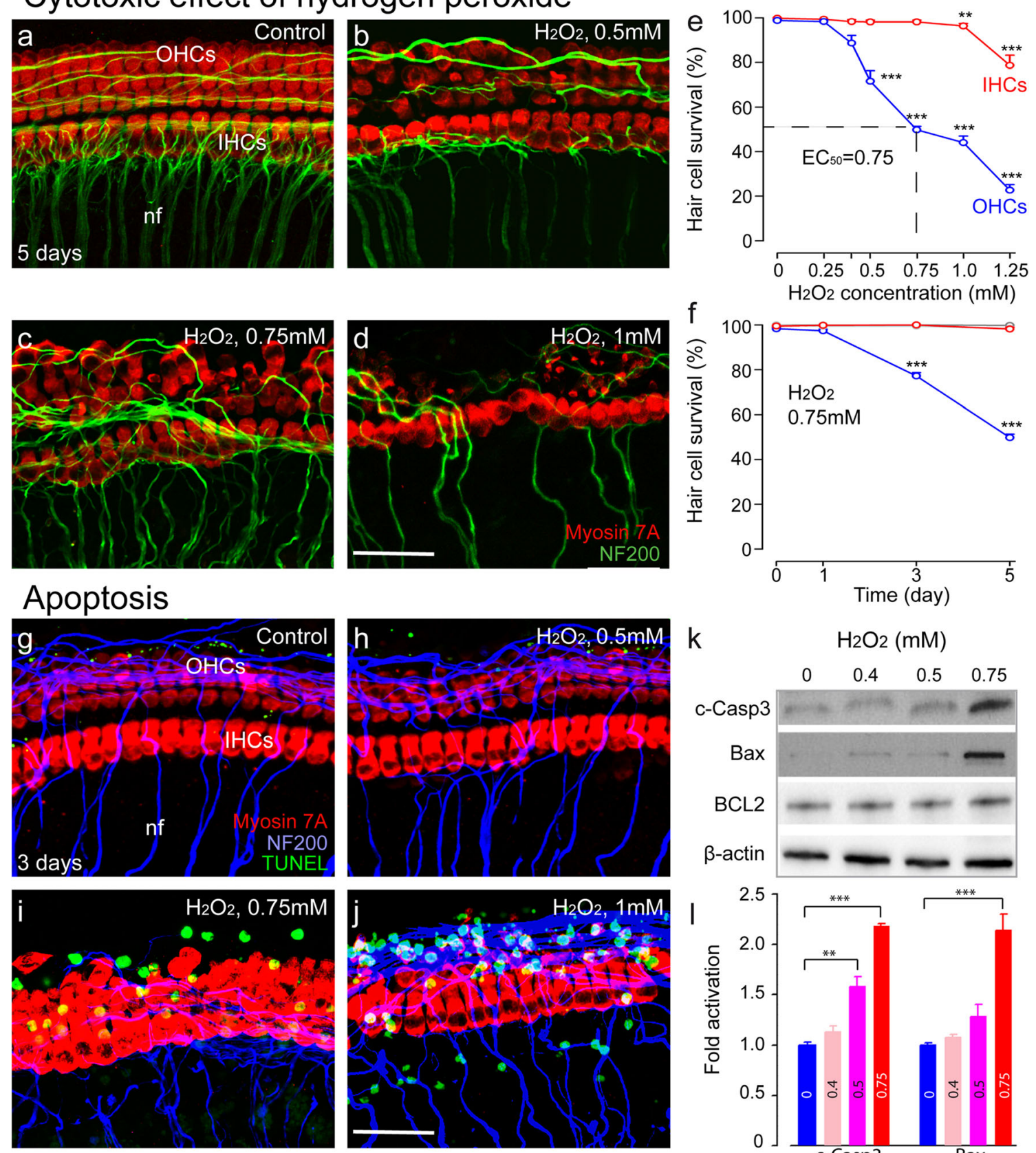

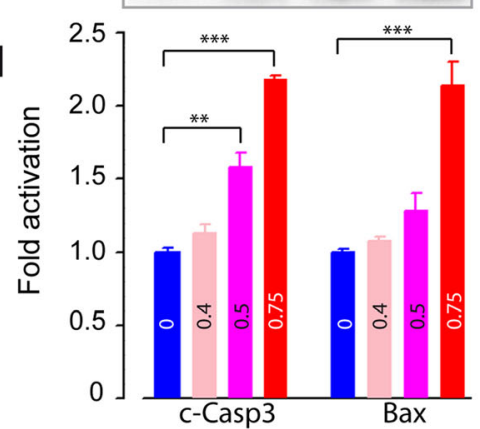

( $0.5 \mathrm{mM}$ of $\mathrm{H}_{2} \mathrm{O}_{2}: \mathrm{F} 1: 6=24.8, P=0.003 ; 0.75 \mathrm{mM}: \mathrm{F} 1: 6=$ $986, P<0.001)$. In addition, higher levels of Bax protein were observed in those exposed to $\geq 0.75 \mathrm{mM}$ of $\mathrm{H}_{2} \mathrm{O}_{2}$ (Fig. 1k, 1 ) $(\mathrm{F} 1: 6=53.6, P<0.001)$. In contrast, Bcl-2 protein levels remained unaltered (Fig. 1k). Taken together, these data demonstrate that $\mathrm{H}_{2} \mathrm{O}_{2}$ induces a concentrationdependent hair cell loss with massive $\mathrm{OHC}$ apoptosis after exposure to high concentrations $(\geq 0.75 \mathrm{mM})$. In an in vivo situation, ROS levels are presumed very low due to their short half-life and the existence of various antioxidant enzymes [32]. On this basis, we chose $\mathrm{H}_{2} \mathrm{O}_{2}$ concentrations $\leq 0.5 \mathrm{mM}$ for subsequent experiments.

\section{Increased Oxidative Stress and Upregulation of Autophagy}

To confirm the occurrence of oxidative stress in cochlear tissues after exposure to $\mathrm{H}_{2} \mathrm{O}_{2}$ at concentrations $\leq 0.5 \mathrm{mM}$, we assessed the activity of antioxidant enzymes such as SOD and catalase (Cat), lipid peroxidation, and the expression levels of SOD2, Cat, p66 ${ }^{\text {Shc }}$ and serine 36-phosphorylated $\mathrm{p} 66^{\text {Shc }}$. $\mathrm{P} 66^{\mathrm{Shc}}$ is a redox protein playing an important role in the regulation of the cellular response to oxidative stress [33]. Three days after $\mathrm{H}_{2} \mathrm{O}_{2}$ exposure, cochleae treated with $0.5 \mathrm{mM} \mathrm{H} \mathrm{H}_{2}$ showed significantly increased SOD activity (Fig. 2a) $(\mathrm{F} 1: 12=28.6, P<0.001)$ and lipid peroxidation 
Fig. 1 Hydrogen peroxide induces apoptosis of the cochlear outer hair cells in a dose and time dependent manner. a-d Confocal images showing the basal regions of cochlear explants treated with either culture medium alone (a) or medium containing $0.5 \mathrm{mM}(\mathbf{b}), 0.75 \mathrm{mM}(\mathbf{c})$, or $1 \mathrm{mM}(\mathbf{d})$ $\mathrm{H}_{2} \mathrm{O}_{2}$ for $5 \mathrm{~h}$ before being maintained in culture medium alone for 5 days. The explants were immunostained with myosin 7A (red) to identify hair cells and with neurofilament 200 (NF200, green) to visualize auditory nerve fibers. Scale bar $=20 \mu \mathrm{m}$. nf, auditory nerve fibers; OHCs, outer hair cells; IHCs, inner hair cells. e Dose-response curves of $\mathrm{H}_{2} \mathrm{O}_{2}$-induced loss of OHCs (blue line) and IHCs (red line) in basal cochlear regions. Data are expressed as mean $\pm \operatorname{SEM}(n=6$ cochleae per condition). One-way ANOVA test followed by post hoc Tukey's test (**P $0.01 ; * * * P \leq 0.001$ vs. $\mathrm{H}_{2} \mathrm{O}_{2} 0 \mathrm{mM}$ ). f Effect over time on OHCs and IHCs of treatment with $0.75 \mathrm{mM} \mathrm{H}_{2} \mathrm{O}_{2}$ (blue and red lines for OHCs and IHCs, respectively) compared with culture medium alone (light blue and red lines for OHCs and IHCs, respectively). Data are expressed as mean \pm SEM ( $n=6$ cochleae per condition and per time point). One-way ANOVA test was followed by post hoc Tukey's test (***P $\leq 0.001$ vs. $\mathrm{H}_{2} \mathrm{O}_{2} 0 \mathrm{mM}$ ). $\mathbf{g}-\mathbf{j}$ Confocal images showing the basal region of cochlear explants treated with either culture medium alone (g) or containing $0.5 \mathrm{mM}(\mathbf{h}), 0.75 \mathrm{mM}(\mathbf{i})$, or $1 \mathrm{mM}(\mathbf{j}) \mathrm{H}_{2} \mathrm{O}_{2}$ for $5 \mathrm{~h}$ before their maintenance in culture medium alone for 3 days. Hair cells were identified using myosin 7A (red) and auditory nerve fibers with neurofilament 200 (NF200 blue). DNA fragmentation was identified using a TUNEL apoptosis kit (green). Scale bar $=35 \mu \mathrm{m}$. $\mathbf{k}$ Representative Western blot analysis using antibodies against cleaved caspase 3 (c-Casp3), Bax, BCL-2, and $\beta$-actin in whole cochlear extracts. 1 Histogram representing the fold change in cleaved caspase 3 and Bax expression levels in control and 0.4, 0.5 , and $0.75 \mathrm{mM} \mathrm{H}_{2} \mathrm{O}_{2}$-exposed groups ( $n=6$ cochleae per condition). $\beta$-Actin served as a loading control. Data are expressed as mean $\pm \mathrm{SEM}$. One-way ANOVA test was followed by post hoc Tukey's test $\left(* * P<0.01, * * * P<0.001\right.$ vs. $\left.\mathrm{H}_{2} \mathrm{O}_{2} 0 \mathrm{mM}\right)$. All experiments were performed in triplicate

(MDA, Fig. 2c) $(\mathrm{F} 1: 12=6.1, P=0.03)$, but significantly decreased catalase activity (Fig. $2 b)(\mathrm{F} 1: 12=27.6, P<0.001)$. Western blot analysis revealed significantly higher levels of SOD2 $\left(0.4 \mathrm{mM}\right.$ of $\mathrm{H}_{2} \mathrm{O}_{2}: \mathrm{F} 1: 6=25.9, P=0.002 ; 0.5 \mathrm{mM}$ : $\mathrm{F} 1: 6=194.9, P<0.001)$, Cat $(0.4 \mathrm{mM}: \mathrm{F} 1: 6=24, P=$ $0.003), \mathrm{p}^{\text {Shc }}(0.5 \mathrm{mM}: \mathrm{F} 1: 6=253, P<0.001)$, and $\mathrm{p}$ p66 ${ }^{\text {Shc }}(0.4 \mathrm{mM}: \mathrm{F} 1: 6=8.5, P=0.027 ; 0.5 \mathrm{mM}: \mathrm{F} 1: 6=109$, $P<0.001)$ in the cochleae exposed to $\mathrm{H}_{2} \mathrm{O}_{2}$ when compared with control-cultured cochleae (Fig. 2d-f). Collectively, these results show that events related to oxidative stress occur after exposure to $\mathrm{H}_{2} \mathrm{O}_{2}$ at low concentrations.

Considering the link between oxidative stress and autophagy [34], we examined autophagy induction by monitoring the levels of proteins involved in autophagosome formation and autophagic flux, the dynamic process of autophagosome synthesis, and degradation. $\mathrm{H}_{2} \mathrm{O}_{2}$-exposed cochleae displayed significantly increased levels of phosphorylated Beclin 1, a major player in the autophagic initiation process [35] (0.4 mM: F1:6 $=24.7, P=0.003 ; 0.5 \mathrm{mM}: \mathrm{F} 1: 6=134.1$, $P<0.001)$; LC3-II $(0.4 \mathrm{mM}: \mathrm{F} 1: 6=10.3, P=0.018$; $0.5 \mathrm{mM}: \mathrm{F} 1: 6=53.7, P<0.001)$, a hallmark of autophagosome formation; and Rab7, a small GTP-binding protein that plays a role in maturation of late autophagic vacuoles [36] (0.4 mM: F1:6 = 57.4, $P<0.001 ; 0.5$ mM: F1:6= $10.2, P=0.029)$ (Fig. 2g, h). Identically, a significant increase of p62, a ubiquitin-binding scaffold protein and a subtract of autophagy, was observed in $0.5 \mathrm{mM} \mathrm{H}_{2} \mathrm{O}_{2}$-exposed cochleae $(\mathrm{F} 1: 6=255, P<0.001)($ Fig. $2 \mathrm{~g}, \mathrm{~h})$. Taken together, these results indicate that $\mathrm{H}_{2} \mathrm{O}_{2}$ induced cochlear cell oxidative stress and triggered an autophagic response.

\section{DNA Damage Responses}

To determine the nature of DNA damage induced by $\mathrm{H}_{2} \mathrm{O}_{2}$ in hair cell nuclei, we used immunolabeling to detect and localize $\mathrm{H} 2 \mathrm{AX}$ phosphorylation $(\gamma \mathrm{H} 2 \mathrm{AX})$ and 53BP1, two hallmarks of DNA damage. $\mathrm{H}_{2} \mathrm{O}_{2}$-intoxicated organ of Corti (Fig. 3c, d) exhibited significantly higher levels of $\gamma \mathrm{H} 2 \mathrm{AX}$ foci formation in both outer hair cells (4.61 \pm 0.55 foci per nucleus) and inner hair cells ( $4.21 \pm$ 0.22 per nucleus) when compared to the control organ of Corti cultures (Fig. 3a, b, $3.22 \pm 0.18$ vs. $2.88 \pm 0.27$ foci per nucleus for $\mathrm{OHC}$ and $\mathrm{IHC}$, respectively) (OHCs: F1:42 $=98.2, P<0.001 ;$ IHCs: $\mathrm{F} 1: 34=286, P<0.001$ ). While the control organ of Corti cultures displayed almost no 53BP1 foci indicative of DNA double-strand breaks $[37,38]$ (Fig. 3e, f), the $0.5-\mathrm{mM} \mathrm{H}_{2} \mathrm{O}_{2}$-intoxicated cochleae showed a large number of 53BP1 foci $(4.27 \pm 1.27$ and $4.25 \pm 0.56$ foci per nucleus for IHC and $\mathrm{OHC}$, respectively) (Fig. $3 \mathrm{~g}, \mathrm{~h}$ ). Concomitantly, Western blots from protein extracts of $\mathrm{H}_{2} \mathrm{O}_{2}$-exposed cochleae revealed strong expression of both $\gamma \mathrm{H} 2 \mathrm{AX}$ and 53BP1 when compared with control-cultured cochleae (Fig. 3i, j) $(\gamma \mathrm{H} 2 \mathrm{AX}$ $0.5 \mathrm{mM}$ of $\mathrm{H}_{2} \mathrm{O}_{2}: \mathrm{F} 1: 6=23.6, P=0.003 ; 53 \mathrm{BP} 1-$ $0.4 \mathrm{mM}$ of $\mathrm{H}_{2} \mathrm{O}_{2}: \mathrm{F} 1: 6=67.9, P<0.001,0.5 \mathrm{mM}$ : $\mathrm{F} 1: 6=205.9, P<0.001)$. Altogether, these results indicate the occurrence of DNA damage, including DNA doublestrand breaks in $\mathrm{H}_{2} \mathrm{O}_{2}$-intoxicated cochleae.

DNA double-strand breaks are potent inducers of DDR, characterized by activation of DDR proteins, including the cell cycle checkpoint proteins like checkpoint kinase 1 (pChk1), checkpoint kinase 2 (p-Chk1), and p53 [39]. Once activated, $\mathrm{p} 53$ plays an important role in modulating distinct cell fate decisions [40-42]. It enhances DNA repair pathways through the upregulation of several repair proteins like the damage-specific DNA binding protein 2 (DDB2), which is required for nucleotide excision repair [43]. We found significant increases in the levels of DDB2 $\left(0.4 \mathrm{mM}\right.$ of $\mathrm{H}_{2} \mathrm{O}_{2}$ : $\mathrm{F} 1: 6=6.0, P=0.049 ; 0.5 \mathrm{mM}: \mathrm{F} 1: 6=12.1, P=0.013)$, pChk2 (0.5 mM: F1:6 $=30, P=0.002)$, and p53 $(0.4 \mathrm{mM}$ : $\mathrm{F} 1: 6=9.2, P=0.023 ; 0.5 \mathrm{mM}: \mathrm{F} 1: 6=25.8, P=0.002)$ in $\mathrm{H}_{2} \mathrm{O}_{2}$-exposed cochleae when compared with the control condition (Fig. 3i, k). In contrast, the increase in the level of pChk1 after $\mathrm{H}_{2} \mathrm{O}_{2}$ challenge did not reach significance (Fig. 3i, k). These results indicate that $\mathrm{H}_{2} \mathrm{O}_{2}$ exposure induces DNA damage and the activation of the Chk2-p53 pathway in postmitotic cochlear cells. 
Oxidative stress related events
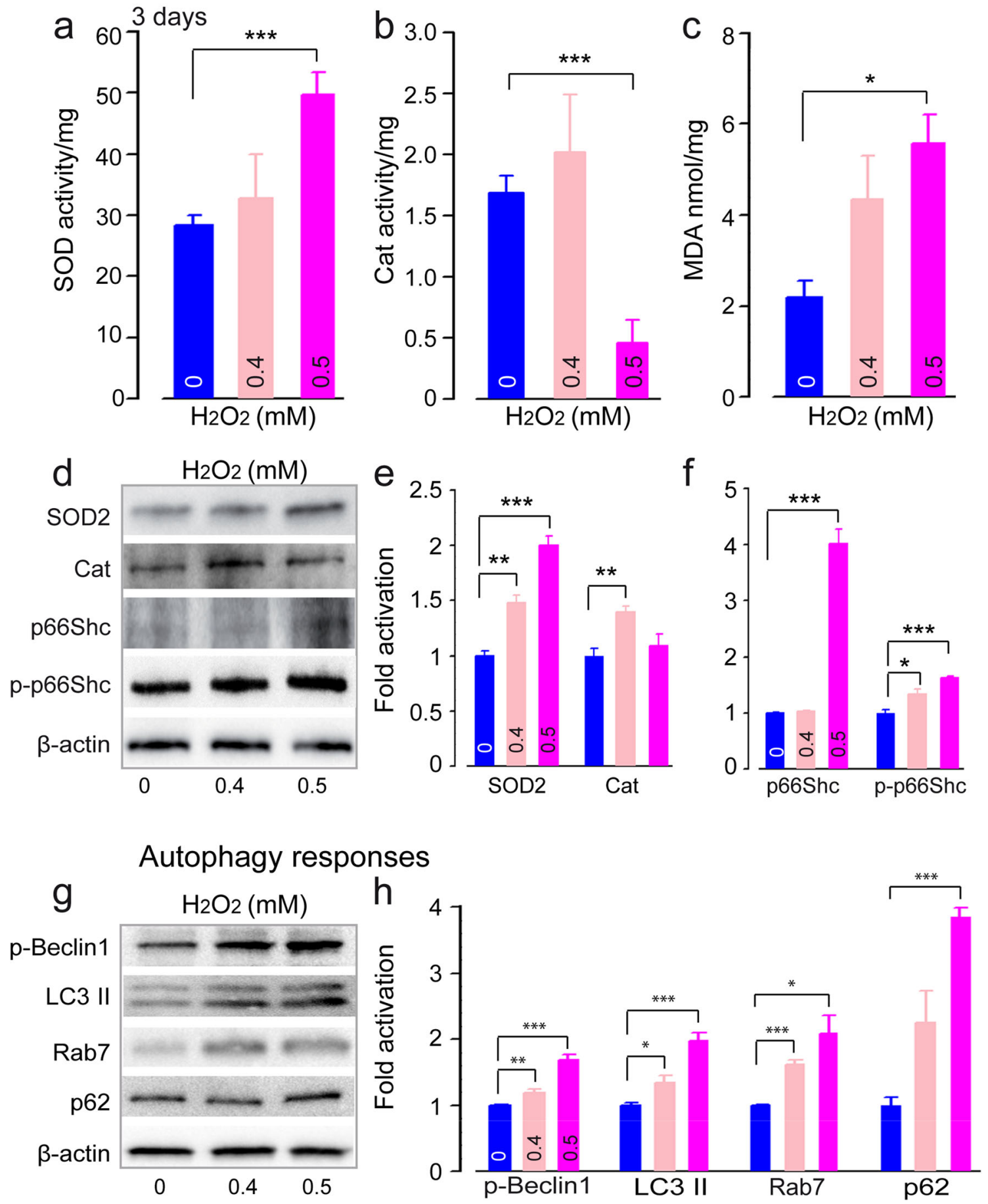

\section{Senescence-Like Phenotype in Postmitotic Cochlear Cells}

To assess whether DDR induces a senescence-like phenotype in postmitotic cochlear cells in vitro, we examined the accumulation of $\mathrm{p} 21$, one of the downstream effectors of $\mathrm{p} 53$. We showed that $0.5 \mathrm{mM} \mathrm{H}_{2} \mathrm{O}_{2}$ resulted in a significant accumulation of p21 (Fig. 4a, b) (F1:6=7.9, P=0.031), suggesting the activation of p53-p21 pathway. Considering both p21- dependent and p21-independent p38MAPK activation may occur in senescence [44], we probed the expression level of p38 and its phosphorylation on threonine-180 and tyrosine182. Consistent with the activation of p53-p21, $\mathrm{H}_{2} \mathrm{O}_{2}$-exposed cochleae showed increased levels of p38 $(0.4 \mathrm{mM}$ : $\mathrm{F} 1: 6=35.4, P=0.001 ; 0.5 \mathrm{mM}: \mathrm{F} 1: 6=11.3, P=0.015)$ and phospho-p38 (0.4 mM: F1:6 $=27.8, P=0.002$; $0.5 \mathrm{mM}$ : F1:6 =52.3, $P<0.001$ ) (Fig. $4 \mathrm{a}, \mathrm{b}$ ). $\mathrm{H}_{2} \mathrm{O}_{2}$ exposure did not 
Fig. 2 Increased oxidative stress and upregulation of autophagy. a-c Quantification analysis of superoxide dismutase (SOD) (a), catalase (Cat) (b), and malondialdehyde (MDA) (c) activities using spectrofluorochemistry in whole cochlear extracts from cochlea treated with culture medium alone (blue bars) or containing $0.4 \mathrm{mM}$ (pale red bars) or $0.5 \mathrm{mM}$ (pink bars) $\mathrm{H}_{2} \mathrm{O}_{2}$ for $5 \mathrm{~h}$. The cochleae were collected from the different conditions after 3 days of culture. All the data are expressed as mean $\pm \operatorname{SEM}$ ( $n=16$ cochleae per condition). One-way ANOVA test was followed by post hoc Tukey's test $(* P \leq 0.04$, *** $P \leq$ 0.001 vs. $\mathrm{H}_{2} \mathrm{O}_{2} 0 \mathrm{mM}$ ). d Representative Western blot analysis using antibodies against SOD2, Cat, p66 ${ }^{\text {Shc }}$, p-p66 ${ }^{\text {Shc }}$, and $\beta$-actin in whole cochlear extracts. e, f Histogram representing the levels of SOD2, Cat, p66 ${ }^{\text {Shc }}$, and p-p66 ${ }^{\text {Shc }}$ in control and 0.4 and $0.5 \mathrm{mM} \mathrm{H}_{2} \mathrm{O}_{2}$-exposed groups ( $n=6$ cochleae per condition). $\beta$-Actin served as a loading control. Data are expressed as mean \pm SEM. One-way ANOVA test followed by post hoc Tukey's test $\left(* P \leq 0.04\right.$, $* * P \leq 0.01$, ***P $\leq 0.001$ vs. $\mathrm{H}_{2} \mathrm{O}_{2}$ $0 \mathrm{mM})$. g Representative Western blot analysis using antibodies against $\mathrm{p}-$ Beclin1, LC3-II, Rab7, p62, and $\beta$-actin in whole cochlear extracts. $\mathbf{h}$ Histograms representing the levels of p-Beclin1, LC3-II, Rab7, and p62 in control and 0.4 and $0.5 \mathrm{mM} \mathrm{H}_{2} \mathrm{O}_{2}$-exposed groups $(n=6$ cochleae per condition). $\beta$-Actin served as a loading control. Data are expressed as mean \pm SEM. One-way ANOVA test followed by post hoc Tukey's test $\left(* P \leq 0.04, * * P \leq 0.01, * * * P \leq 0.001\right.$ vs. $\left.\mathrm{H}_{2} \mathrm{O}_{2} 0 \mathrm{mM}\right)$. All experiments were performed in triplicate

significantly affect the expression level of p16, a cell cycle inhibitor. However, the cell cycle regulator p19 $(0.5 \mathrm{mM}$ of $\left.\mathrm{H}_{2} \mathrm{O}_{2}: \mathrm{F} 1: 6=13.4, P=0.011\right)$ and the mitotic checkpoint protein BubR1 (0.4 mM: F1:6=9.8, $P=0.02 ; 0.5 \mathrm{mM}: \mathrm{F} 1: 6=$ $27, P=0.002$ ) were significantly repressed (Fig. $4 \mathrm{a}, \mathrm{c}$ ). Concomitantly, $\mathrm{H}_{2} \mathrm{O}_{2}$-exposed cochleae showed increased activity of SA- $\beta$-gal, a widely accepted general marker of the senescent phenotype [45] (Fig. 4d). Altogether, these data firmly demonstrate the occurrence of a senescence-like phenotype in postmitotic cochlear cells after $\mathrm{H}_{2} \mathrm{O}_{2}$ challenge.

\section{Pharmacological Mitigation of ROS with EUK-207}

To probe the impact of ROS mitigation on $\mathrm{H}_{2} \mathrm{O}_{2}$-induced DNA damage and senescence-like phenotype, we aimed to counteract excessive ROS by pre- and posttreating cochleae with $10 \mu \mathrm{M}$ EUK-207, a potent synthetic superoxide dismutase/catalase mimetic that scavenges superoxide and hydrogen peroxide [46]. As a readout, we first analyzed the expression of Foxo3a, a forkhead transcription factor of the Foxo class, which is known to reduce the level of cellular oxidative stress by directly increasing mRNA and protein levels of MnSOD and catalase [47]. We found that treatment with EUK-207 alone significantly increased the levels of Foxo3a (Fig. 5a, b) $(\mathrm{F} 1: 6=8.9, P=0.029)$. We also established that EUK-207 alone increased the Nrf2 levels (Fig. $5 \mathrm{a}, \mathrm{c})(\mathrm{F} 1: 6=157.2, P<0.001)$, but significantly reduced $\gamma \mathrm{H} 2 \mathrm{AX}$ levels (Fig. 5a, d) $(\mathrm{F} 1: 6=65.2, P<0.001)$. Interestingly, a combined treatment with $10 \mu \mathrm{M}$ EUK-207 and $0.5 \mathrm{mM} \mathrm{H}_{2} \mathrm{O}_{2}$ significantly increased the expression levels of Foxo3a and Nrf2 when compared with the control (Foxo3a: F1:6 $=118.2, P<0.001 ;$ Nrf2: F1:6 $=751.2$,
$P<0.001$ ) or $\mathrm{H}_{2} \mathrm{O}_{2}$ alone (Foxo3a: $\mathrm{F} 1: 6=124.8, P<0.001$; Nrf2: F1:6 $=221.2, P<0.001$ ) (Fig. $5 \mathrm{a}-\mathrm{c}$ ). In contrast, this combination efficiently attenuated the induction of $\gamma \mathrm{H} 2 \mathrm{AX}$ by $\mathrm{H}_{2} \mathrm{O}_{2}$ (Fig. $\left.5 \mathrm{a}, \mathrm{d}, \mathrm{h}-\mathrm{i}\right)(\mathrm{F} 1: 6=174.8, P<0.001)$. Finally, we also report that this combined treatment significantly increased p19 expression (Fig. 5a, e) (F1:6 $=8.9, P=0.025)$, but did not significantly reduce p21 level (Fig. $5 \mathrm{a}, \mathrm{f}$ ). Taken together, these results demonstrate that by counteracting excessive ROS, EUK-207 may attenuate oxidative stress-induced DNA damage and senescence phenotype.

\section{In Vivo Validation in Adult SAMP8 Mice}

\section{Molecular Pathway Validation}

SAMP8 mice have been shown to display premature hearing loss and cochlear degeneration associated with oxidative stress and altered levels of antioxidant enzymes [4]. Here, we probed whether cochlear cells engender similar DNA damage responses and senescence signatures during premature aging in vivo. We first analyzed Nrf2, emerging as a regulator of cellular resistance to oxidants [48]. Western blot analyses revealed a significant decrease in $\mathrm{Nrf2}$ with age in both strains (Fig. 6a, b) (SAMR1: 6 months: F1:6 $=9.7, P=0.021$, 12 months: F1:6 $=92.9, P<0.001$; SAMP8: 6 months: F1:6=7.9, $P=0.031,12$ months: F1:6=78.2, $P<0.001$ ). However, SAMP8 mice systematically showed significantly lower expression levels compared to the control SAMR1 mouse strains at all ages analyzed (Fig. 6a, b) (1 month: F1: $6=104.5, P<0.001 ; 6$ months: F1: $6=82.6, P<0.001$; 12 months: $\mathrm{F} 1: 6=14.6, P=0.009)$. Interestingly, this much decreased Nfr2 expression was detectable from 1 month of age in SAMP8 mice (Fig. 6a, b). Similarly, while SAMP8 mice displayed a significantly lower level of MnSOD (SOD2) expression starting early from 1 month of age and maintained to 12 months (Fig. 6a, b) (1 month: F1:10= 69.6, $P<0.001 ; 6$ months: $\mathrm{F} 1: 10=17.6, P=0.002)$, SAMR1 mice only showed such decrease in SOD2 at 12 months of age (Fig. 6a, b) (F1:10 =14.6, $P=0.003$ ). SAMP8 mice showed significantly higher levels of $\mathrm{p} 66^{\mathrm{Shc}}$ (1 month: F1:6 $=10.4, P=0.029 ; 6$ months: $\mathrm{F} 1: 6=657$, $P<0.001 ; 12$ months: $\mathrm{F} 1: 6=598.7, P<0.001)$ and phorphorylated $\mathrm{p} 66^{\text {Shc }}$ (p-p66 ${ }^{\text {Shc }}, 6$ months: F1:6 $=24.1$, $P=0.003 ; 12$ months: F1:6 $=136.6, P<0.001)$ when compared with SAMR1 mice of the same age (Fig. 6a, c). They also showed dramatic increases in the amounts of $\mathrm{p} 66^{\text {Shc }}$ (6 months: F1: $6=19.7, P=0.004 ; 12$ months: F1: $6=108.9$, $P<0.001)$ and p-p66 ${ }^{\text {Shc }}(6$ months: F1:6 $=21.9, P=0.003$; 12 months: $\mathrm{F} 1: 6=125.8, P<0.001)$ during the aging process (Fig. 6a, c). In contrast, SAMR1 mice showed reduced levels of p-p $66^{\text {Shc }}$ at 12 months compared to 1 month of age (Fig. 6 a, c; F1:6 $=19.5, P=0.004)$. Taken together, these results 
DNA damage
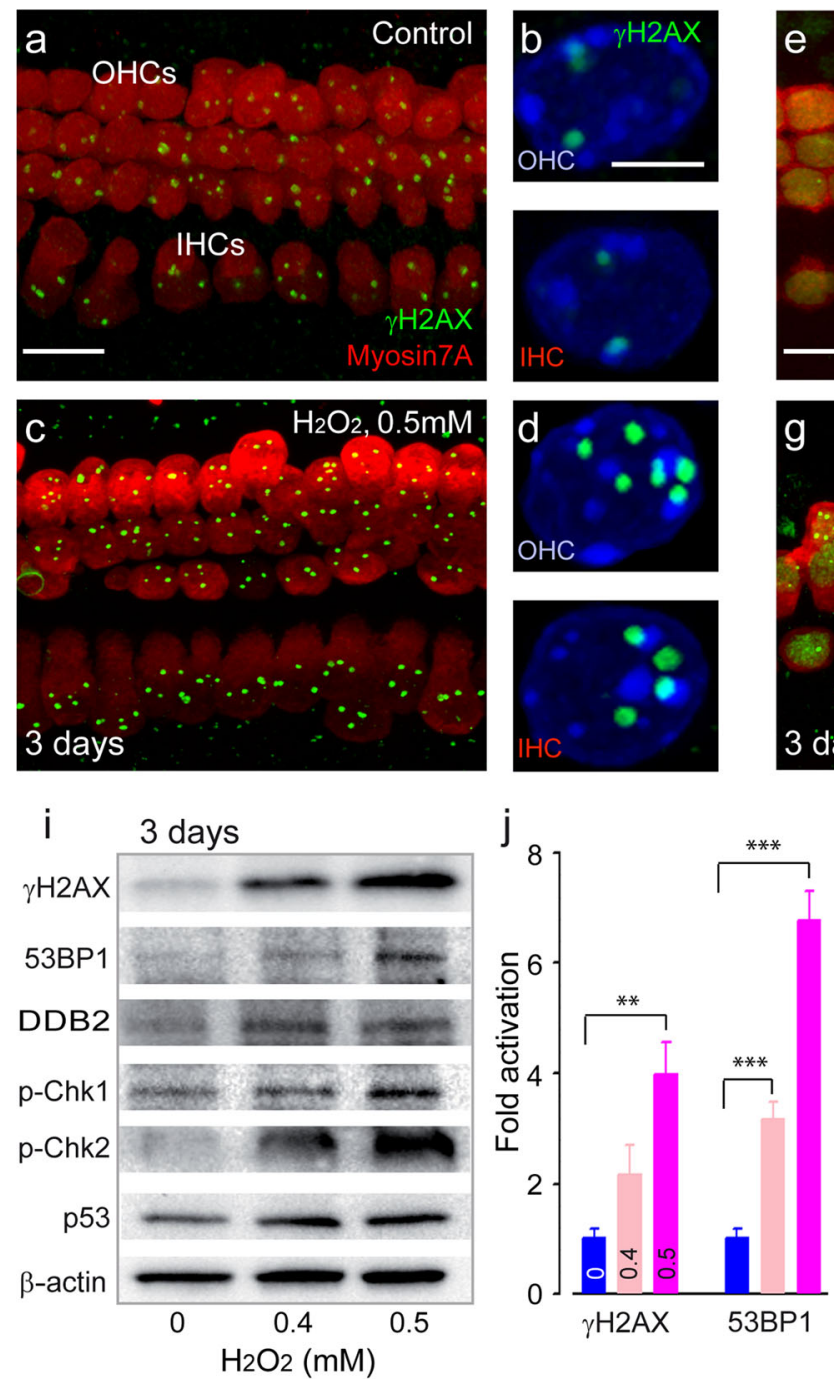

Fig. 3 DNA damage and DNA damage responses upon $\mathrm{H}_{2} \mathrm{O}_{2}$ challenge. $\mathbf{a}, \mathbf{c}, \mathbf{e}, \mathbf{g}$ Confocal images showing the basal region of the organ of Corti cultures treated with either culture medium alone $(\mathbf{a}, \mathbf{e})$ or containing $0.5 \mathrm{mM} \mathrm{H}_{2} \mathrm{O}_{2}(\mathbf{c}, \mathbf{g})$ for $5 \mathrm{~h}$ before being maintained in culture medium alone for 3 days. The samples were then immunolabeled for myosin 7A (red, a, c, e, g), $\gamma \mathrm{H} 2 \mathrm{AX}$ (green, $\mathbf{a}$ and $\mathbf{c}$ ) and 53BP1 (green, e and $\mathbf{g}$ ). Scale bars: a, $\mathbf{c}, \mathbf{e}$ and $\mathbf{g}=10 \mu \mathrm{m}$. b, $\mathbf{d}, \mathbf{f}, \mathbf{h}$ Higher magnification images of representative $\mathrm{OHC}$ and IHC nuclei from all conditions tested. Scale bar $=2.5 \mu \mathrm{m}$. i Representative Western blot analysis using antibodies

indicate the earlier occurrence ( 1 month old) and a higher level of oxidative stress in the cochleae of SAMP8 mice.

As expected, SAMP8 mice displayed a significant increase in phosphorylated Beclin 1 (6 months: F1:6 $=114.8, P<$ $0.0001 ; 12$ months: F1:6 $=78, P=0.006)$ and Rab7 (6 months: F1: $6=82, P=0.0001 ; 12$ months: F1:6 $=85.3, P=0.0001$ ) from 6 months of age. In contrast, SAMR1 mice only showed such increases (p-Beclin 1: F1:6 $=167, P<0.0001$; Rab7: $\mathrm{F} 1: 6=26.3, P=0.0022)$ at 12 months of age. SAMP8 mice also showed significantly higher levels of phosphorylated Beclin 1 (6 months: F1:6 $=108, P<0.0001 ; 12$ months:
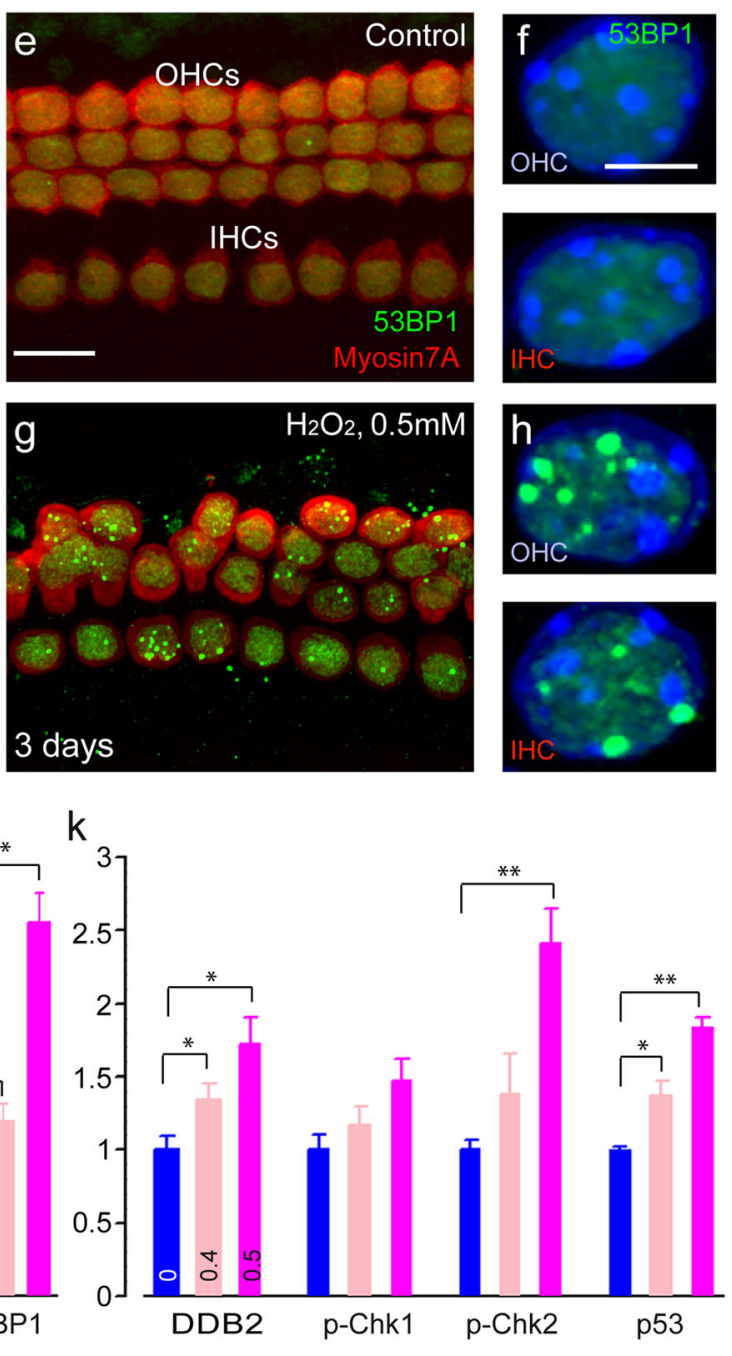

against $\gamma \mathrm{H} 2 \mathrm{AX}, 53 \mathrm{BP} 1, \mathrm{DDB} 2, \mathrm{p}$-Chk1, p-Chk2, p53, and $\beta$-actin in whole cochlear extracts. $\mathbf{j}$, $\mathbf{k}$ Histograms representing the levels of $\gamma \mathrm{H} 2 \mathrm{AX}, 53 \mathrm{BP} 1, \mathrm{DDB} 2, \mathrm{p}-\mathrm{Chk} 1, \mathrm{p}-\mathrm{Chk} 2$, and 553 in control and in 0.4 and $0.5 \mathrm{mM} \mathrm{H}_{2} \mathrm{O}_{2}$-exposed groups ( $n=6$ cochleae per condition). $\beta$-Actin served as a loading control. Data are expressed as mean \pm SEM. One-way ANOVA test followed by post hoc Tukey's test $(* P \leq$ $0.04, * * P \leq 0.01, * * * P \leq 0.001$ vs. $\left.\mathrm{H}_{2} \mathrm{O}_{2} 0 \mathrm{mM}\right)$. All experiments were performed in triplicate

F1:6 $=73.3, P=0.0001)$ and Rab7 (6 months: F1:6 $=76$, $P=0.0001 ; 12$ months: F1:6 $=21.2, P=0.0036)$ than SAMR1 mouse strains at the same age (Fig. $6 \mathrm{~d}$, e). Not surprisingly, a significant higher level of p62 was observed in SAMP8 mice at 6 months compared with SAMR1 of the same age $(\mathrm{F} 1: 6=9.48, P=0.022)$. While p62 levels maintained in SAMP8 mice during aging, these levels decreased significantly in SAMR1 mice at 6 months when compared with 1 month (F1:6 $=8.98, P=0.0241)$. Taken together, these results indicate an increased autophagy with impaired autophagic flux in SAMP8 mice. 


\section{Senescence-like phenotype}
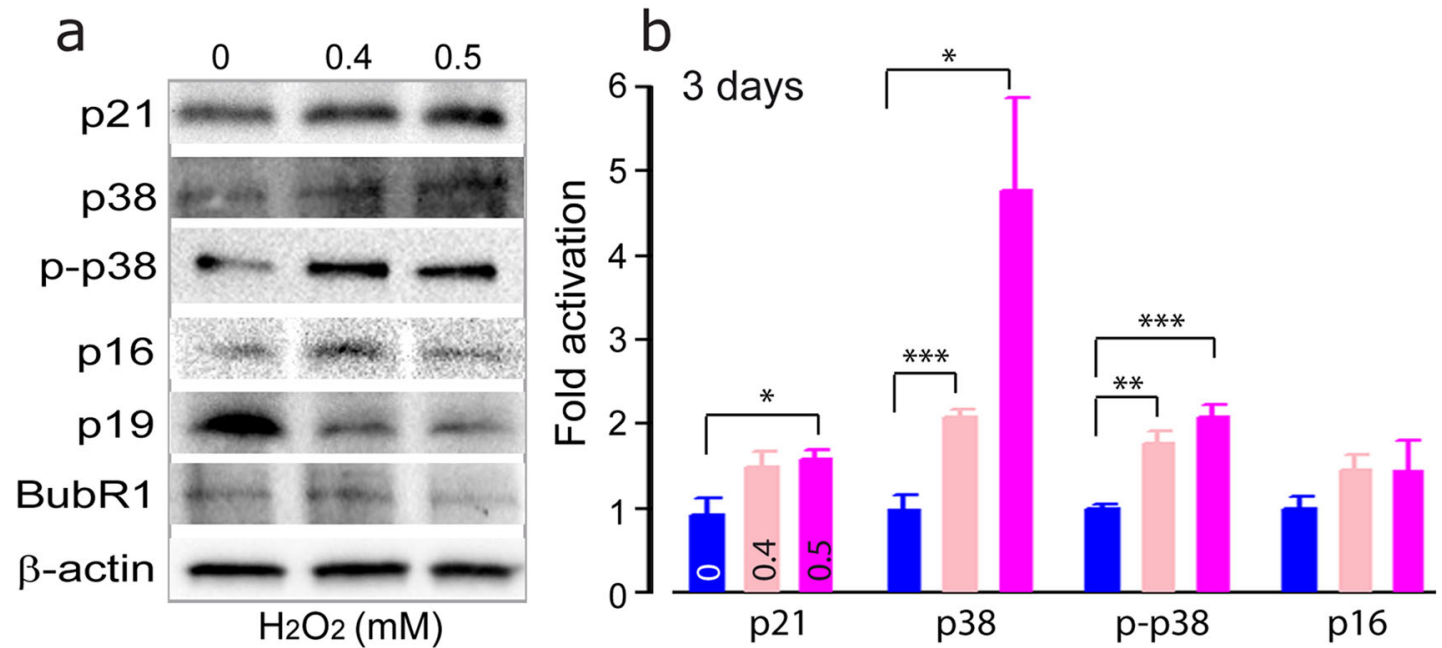

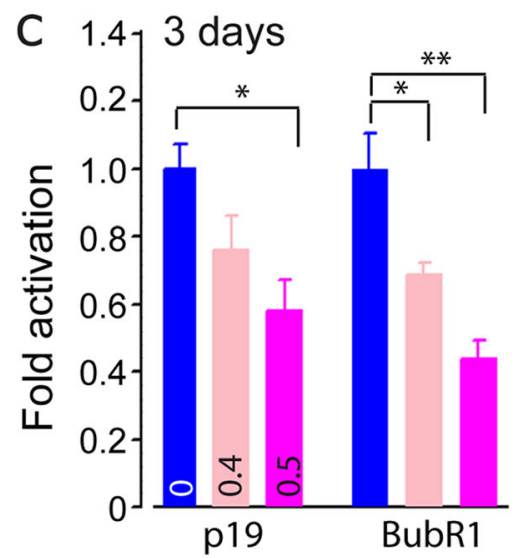

Fig. 4 Senescence-like phenotype upon $\mathrm{H}_{2} \mathrm{O}_{2}$ treatment. a Representative Western blot analysis using antibodies against p21, p38, p-p38, p16, p19, BubR1, and $\beta$-actin in whole cochlear extracts. b, c Histograms representing the levels of p21, p38, p-p38, p16, p19, and BubR1 in 0 (control), 0.4 , and $0.5 \mathrm{mM} \mathrm{H}_{2} \mathrm{O}_{2}$-exposed groups $(n=6$ cochleae per condition). $\beta$-Actin served as a loading control. Data are expressed as mean \pm SEM. One-way ANOVA test followed by post hoc Tukey's test $\left(* P \leq 0.05, * * P \leq 0.01, * * * P \leq 0.001\right.$ vs. $\left.\mathrm{H}_{2} \mathrm{O}_{2} 0 \mathrm{mM}\right)$. d Light microscope images showing the basal region of the organ of Corti

To further explore the potential appearance of DDR in SAMP8 mice, we assessed DDR proteins. Western blot analysis demonstrated dramatic increases in p-Chk2 levels from as early as 6 months in SAMP8 mouse cochleae (6 months: F1:6 $=161.9, P<0.001 ; 12$ months: F1:6= 292, $P<0.001$ ), while such an increase was only seen in 12-month-old SAMR1 mice $(\mathrm{F} 1: 6=209.5, P<0.001)$ compared to 1-month olds (Fig. 6f, g). In addition, significantly higher levels of p-Chk2 were observed in SAMP8 than SAMR1 mice of the same age $(6$ months: F1:6= 151.4, $P<0.001 ; 12$ months: F1:6=199, $P<0.001$ ) (Fig. 6f, g). Similarly, SAMP8 mice showed significantly increased p53 (6 months: F1:6 $=11.2, P=0.029$; cultures treated with either culture medium alone or containing $0.5 \mathrm{mM}$ $\mathrm{H}_{2} \mathrm{O}_{2}$ for $5 \mathrm{~h}$ before their maintenance in culture medium alone for 3 days. The samples were then stained with fresh $\beta$-galactosidase (SA- $\beta$-gal) solution at $\mathrm{pH}$ 6.0. Note that $\mathrm{H}_{2} \mathrm{O}_{2}$ exposure resulted in an increased activity of SA- $\beta$-gal (blue) in OHCs and supporting cells located in the area of the organ of Corti as well as in the cells located in the region of the spiral ganglion $(\mathrm{SG})$. Scale $b a r=25 \mu \mathrm{m}$. All experiments were performed in triplicate

12 months: $\mathrm{F} 1: 6=358.6, P<0.001)$ and $\mathrm{p}-\mathrm{p} 53$ levels (6 months: F1:6 $=11.1, P=0.029 ; 12$ months: F1:6= 129.8, $P<0.001$ ) from 6 months (Fig. 6f, g). The same phenomenon occurred in SAMR1 but at a later stage (at 12 months, p53: F1:6 $=10.9, P=0.029$; p-p53: F1:6= 70.7, $P<0.001$, Fig. 6f, g). However, changes were more pronounced in SAMP8 than in SAMR1 mice (p53: 6 months: $\mathrm{F} 1: 6=11, P=0.029,12$ months: $\mathrm{F} 1: 6=$ 181.6, $P<0.001 ;$ p-p53: 6 months: F1:6=11.2, $P=$ 0.029, 12 months: F1:6 $=84.1 .2, P<0.001$, Fig. 6 f, g). Together, these results point toward the activation of a DNA damage response during cochlear aging, with more severe effects in SAMP8 compared to SAMR1 mice. 
Fig. 5 EUK-207 upregulates antioxidant response elements and suppresses DNA damage and senescence phenotype. a Representative Western blot analysis using antibodies against FOXO3a, Nrf2, $\gamma \mathrm{H} 2 \mathrm{AX}, \mathrm{p} 19$, $\mathrm{p} 21$, and $\beta$-actin in whole cochlear extracts. b-f Histograms representing the levels of FOXO3a, Nrf2, $\gamma$ H2AX, p19, and $\mathrm{p} 21$ in control (Ctrl), $10 \mu \mathrm{M}$ EUK-207 alone, and $0.5 \mathrm{mM}$ $\mathrm{H}_{2} \mathrm{O}_{2}$ alone or in combination with $10 \mu \mathrm{M}$ EUK-207 exposed groups ( $n=6$ cochleae per condition). $\beta$-Actin served as a loading control. Data are expressed as mean \pm SEM. One-way ANOVA test followed by post hoc Tukey's test $(* P \leq 0.04, * * P \leq 0.01$, $* * * P \leq 0.001$ vs. Ctrl; ${ }^{\#} P \leq 0.025$, ${ }^{\#} P \leq 0.01,{ }^{\# \#} P \leq 0.001$ vs. $\mathrm{H}_{2} \mathrm{O}_{2}$ $0.5 \mathrm{mM}) . \mathbf{g}-\mathbf{i}$ Confocal images showing the basal region of organ of Corti cultures treated with either culture medium alone (control, g) or with medium containing $0.5 \mathrm{mM} \mathrm{H}_{2} \mathrm{O}_{2}$ (h) or $0.5 \mathrm{mM}$ $\mathrm{H}_{2} \mathrm{O}_{2}$ in combination with $10 \mu \mathrm{M}$ EUK-207 (i) for 3 days. The samples were then immunolabeled for myosin 7A (red) and $\gamma \mathrm{H} 2 \mathrm{AX}$ (green). Scale bar $=15 \mu \mathrm{m}$. All experiments were performed in triplicate

\section{DNA damage inhibition properties of EUK-207 in vitro}
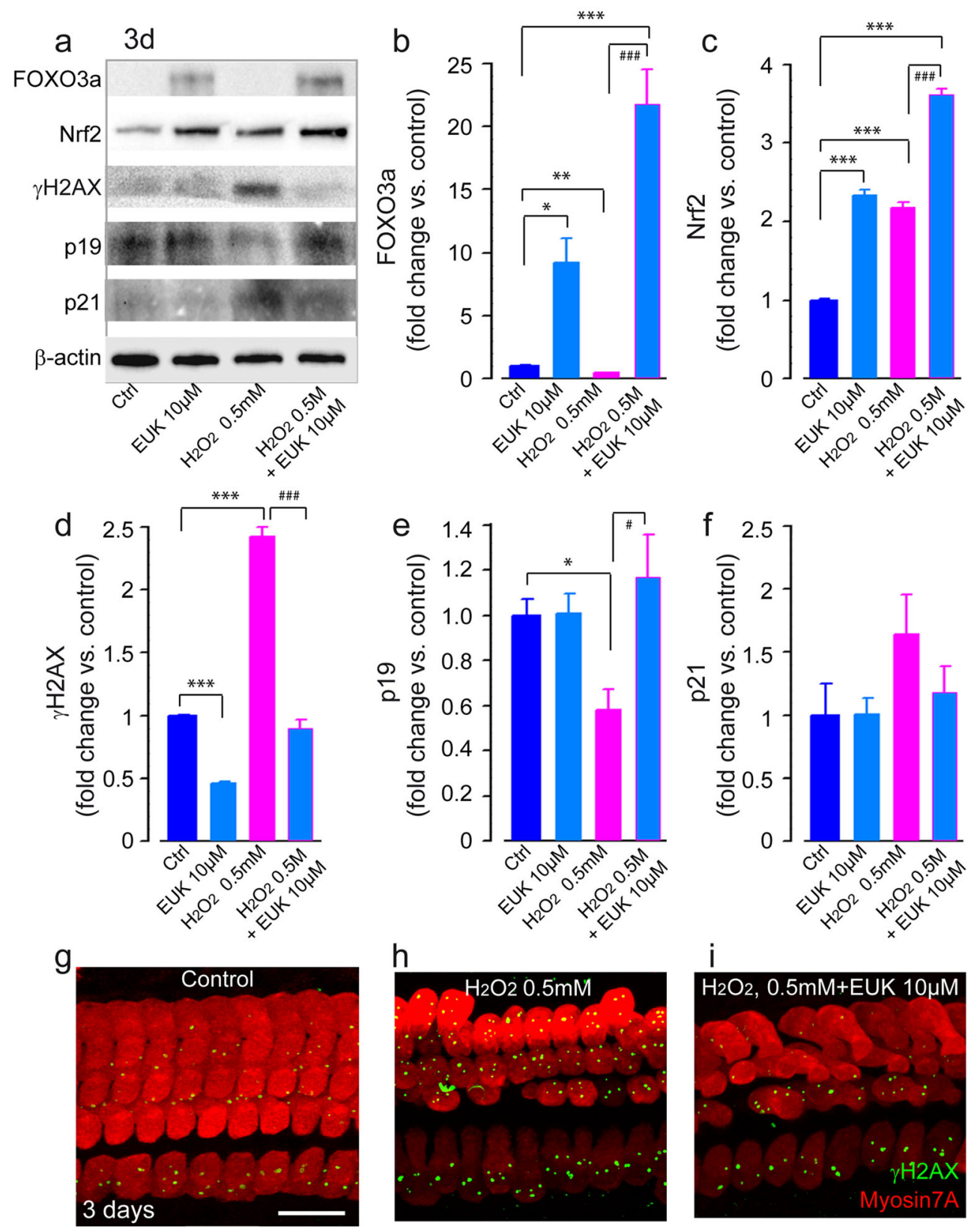

In addition, both strains displayed an increase in senescence-like features, characterized by an increase in the levels of p21 (SAMP8: 6 months: F1:6=44.4, $P<0.001$, 12 months: F1:6 =84.3, $P<0.001$; SAMR1: 6 months: F1:6=151.8, $P<0.001,12$ months: F1: $6=78.1, P<0.001$, Fig. $7 \mathrm{a}, \mathrm{b})$ and p16 during aging (SAMP8: 6 months: F1:6= 11, $P=0.03$, 12 months: F1:6=10.1, $P=0.029$; SAMR1: 12 months: F1:6=14.6, $P=0.009$, Fig. 7a, b). However, here again, changes were more pronounced in SAMP8 than in SAMR1 mice (p21: 6 months: F1:6 $=28.5, P=0.002$, 12 months: F1:6=46, $P<0.001 ;$ p16: 6 months: F1:6= 31.9, $P<0.001,12$ months: F1:6=23.2, $P=0.003$, Fig. 7 a, b). SAMP8 mice also showed significantly decreased levels of BubR1 at 12 months (F1:6=51.2, $P<0.001$ vs. 1 month age). In addition, significantly lower level of BubR1 was observed in SAMP8 than SAMR1 mice at 12 months $(\mathrm{F} 1: 6=30.2, P=0.002$, Fig. $7 \mathrm{a}, \mathrm{c})$. By contrast, an increased level of p19 was only observed in SAMP8 mice at 6 months $(\mathrm{F} 1: 6=31.2, P=0.001$ vs. 1 month age; F1:6= $27, P=0.002$ vs. SAMR1 of the same age, Fig. 7a, c). Accordingly, 6-month-old SAMP8 mouse cochleae showed increased activity of SA- $\beta$-gal mainly in the spiral ganglion neurons, OHCs, and IHCs (Fig. 7e, h-i, m-o) when compared with SAMR1 mice of the same age (Fig. 7d, f, g, j-1). 


\section{Oxidative stress related events}
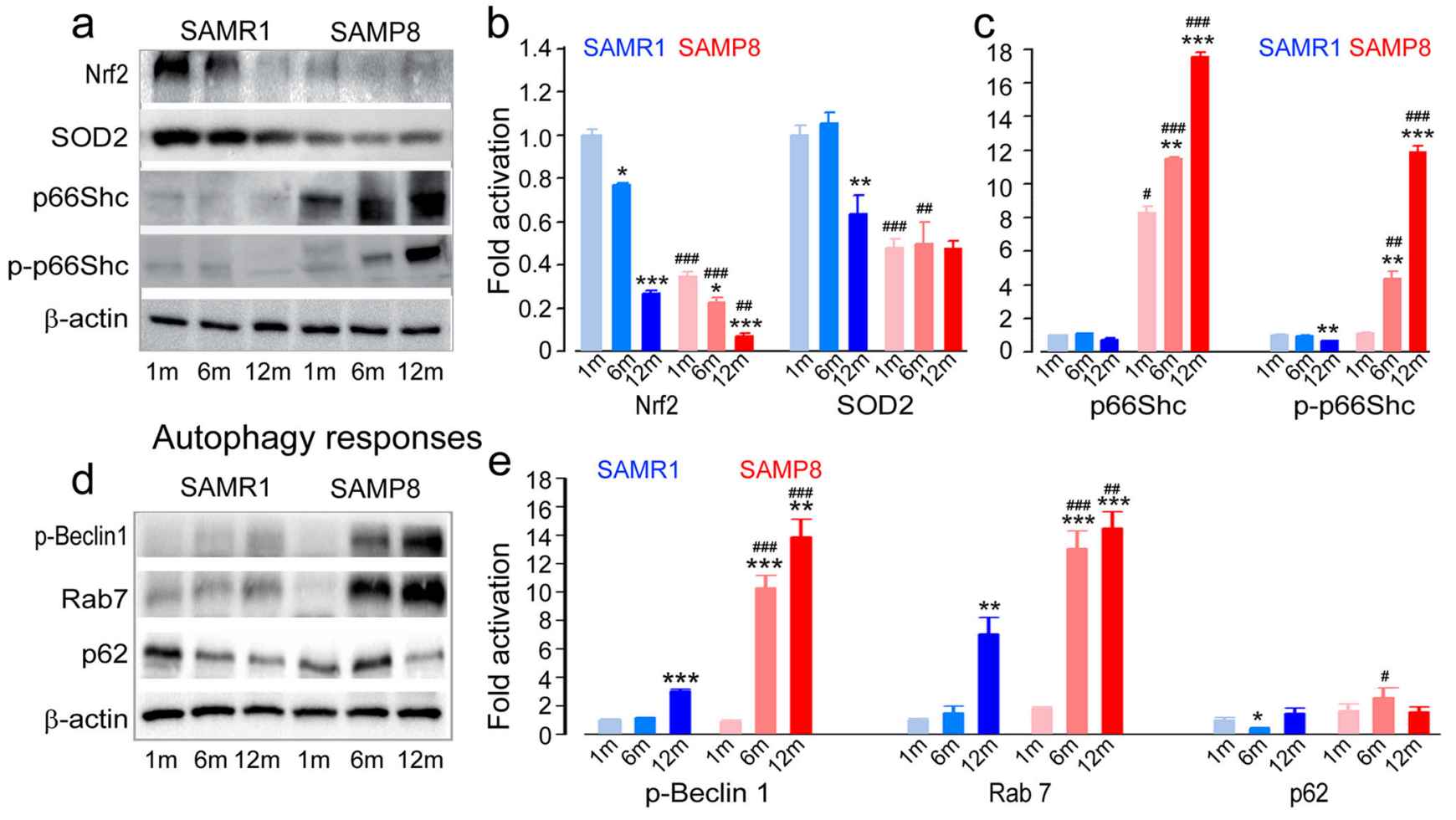

DNA damage response
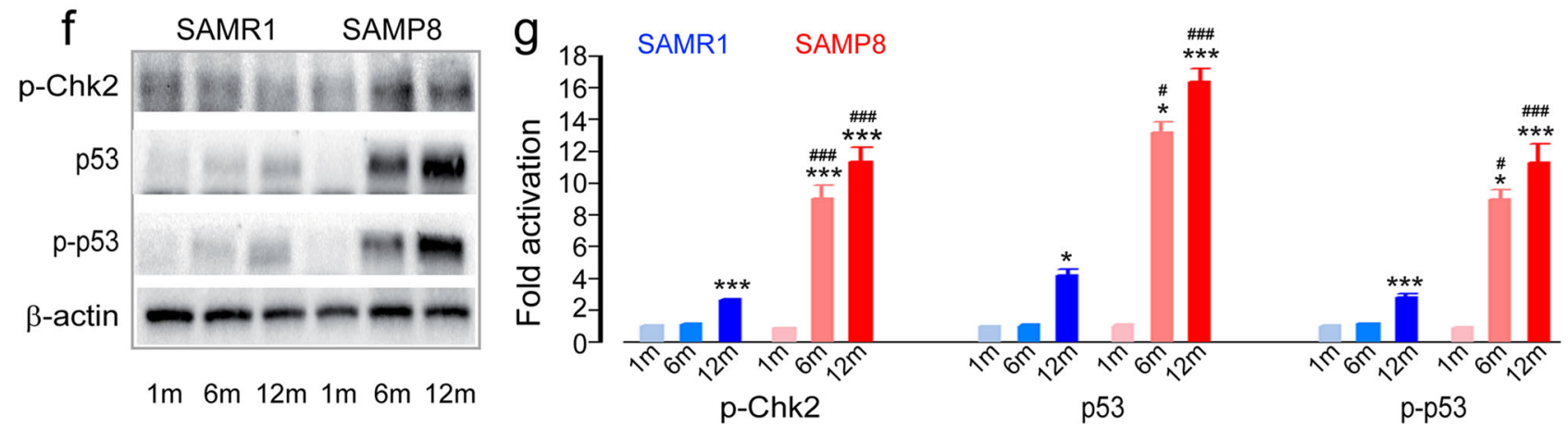

Fig. 6 Increased oxidative stress, upregulation of autophagy, and activation of DDR in adult SAMP8. a, d, $\mathbf{f}$ Representative Western blot analysis using antibodies against Nrf2, SOD2, p66 ${ }^{\text {Shc }}, \mathrm{p}-\mathrm{p} 66^{\mathrm{Shc}}$, pBeclin1, Rab7 p62, p-Chk2, p53, p-p53, and $\beta$-actin in whole cochlear extracts. b, c Histograms representing the levels of Nrf2, SOD2, p66 ${ }^{\mathrm{Shc}}$, and p-p66 ${ }^{\text {Shc }}$ in SAMR1 and SAMP8 mice aged 1, 6, and 12 months $(n=$ 16 cochleae per strain and per age) $(* P \leq 0.05, * * P=0.01$, *** $P \leq 0.001$ vs. 1 month age; ${ }^{\#} P \leq 0.042,{ }^{\# \#} P \leq 0.01,{ }^{\# \# \#} P \leq 0.001$ vs. SAMR 1 of the same age). e Histograms representing the levels of p-Beclin1, Rab7, and p62 in SAMR1 and SAMP8 mice aged 1,6 , and 12 months $(n=16$

\section{Correlation Between Molecular Events and Hearing Loss}

The ABR threshold showed no significant difference between SAMP8 and SAMR1 mice at 1 month (Fig. 8a-c). In contrast, both strains of mice showed an age-related hearing loss after 1 month of age but was twice as severe in SAMP8 $(5 \mathrm{~dB} /$ month, $R=0.9, P<0.001)$ than in cochleae per strain and per age) $(* P=0.024, * * P \leq 0.01, * * * P \leq 0.001$ vs. 1 month age; ${ }^{\#} P=0.022,{ }^{\# \#} P=0.0036,{ }^{\# \#} P \leq 0.001$ vs. SAMR1 of the same age). $g$ Histograms representing the levels of p-Chk2, p53, and p-p53 in SAMR1 and SAMP8 mice aged 1, 6, and 12 months $(n=16$ cochleae per strain and per age) $(* P \leq 0.043, * * P \leq 0.01, * * * P \leq 0.001$ vs. 1 month age; ${ }^{\#} P \leq 0.025,{ }^{\# \#} P \leq 0.01,{ }^{\# \# \#} P \leq 0.001$ vs. SAMR 1 of the same age). $\beta$-Actin served as a loading control. Data are expressed as mean \pm SEM. One-way ANOVA test followed by post hoc Tukey's test. All experiments were performed in triplicate

SAMR 1 mice $(2.8 \mathrm{~dB} /$ month, $R=0.62, P<0.001$, Fig. $8 \mathrm{c})$. To facilitate the comparison between the two strains of mice, we expressed all the functional data obtained in SAMP8 with respect to those in SAMR1. We then expressed the molecular events as a function of hearing threshold shift with respect to the control SAMR1. When the molecular event was close to zero, hearing loss was 

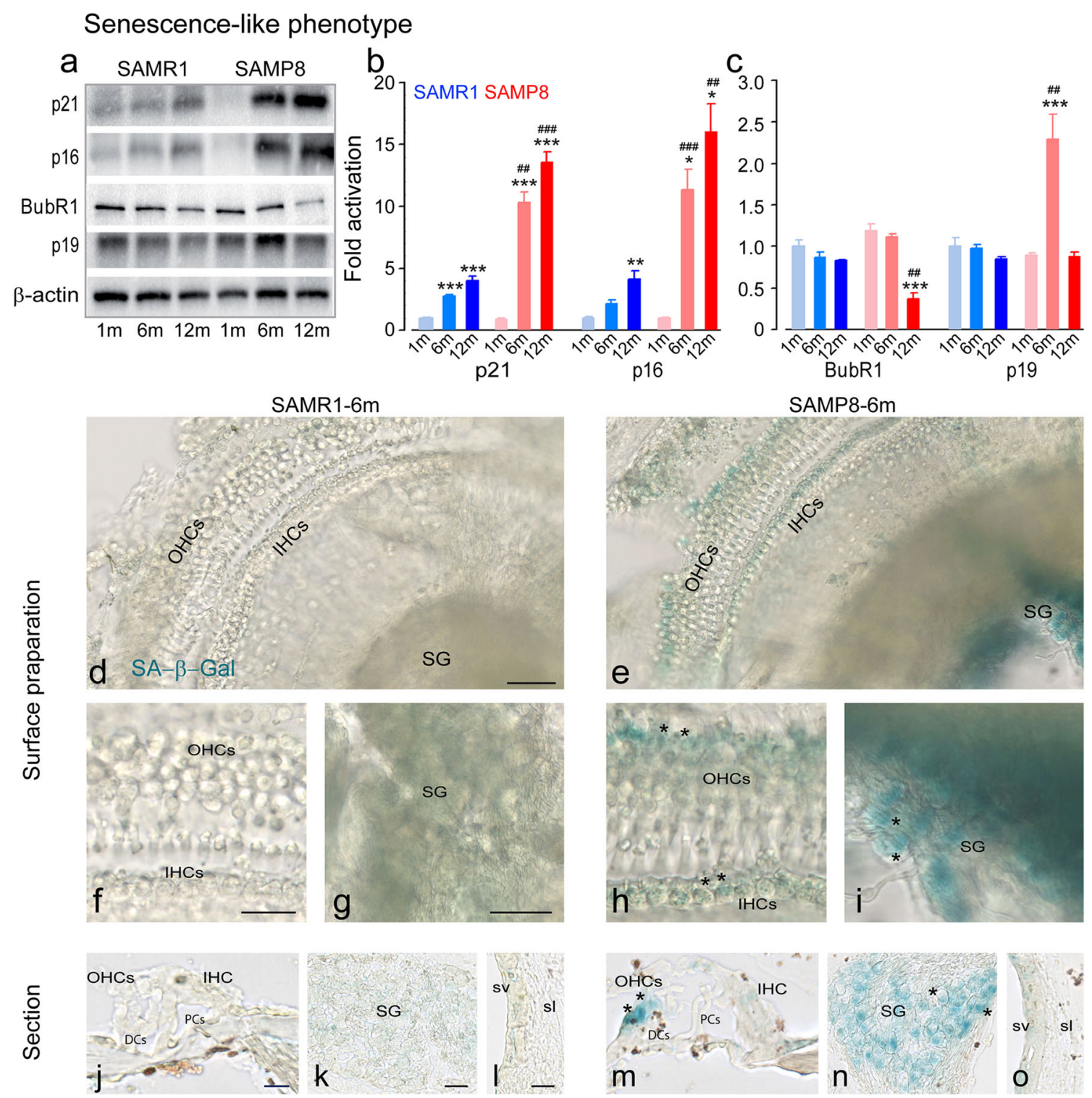

Fig. 7 Senescence-like phenotype in adult SAMP8. a Representative Western blot analysis using antibodies against p21, p16, BubR1, p19, and $\beta$-actin in whole cochlear extracts. $\mathbf{b}, \mathbf{c}$ Histograms representing the levels of p21, p16, BubR1, p19, and $\beta$-actin in SAMR1 and SAMP8 mice aged 1,6 , and 12 months ( $n=16$ cochleae per strain and per age). $\beta$-Actin served as a loading control. Data are expressed as mean \pm SEM. One-way ANOVA test was followed by post hoc Tukey's test $(* P \leq 0.035, * * P=$ $0.01, * * * P=0.001$ vs. 1 month age; ${ }^{*} P \leq 0.041,{ }^{\# \#} P \leq 0.01,{ }^{\# \# \#} P \leq 0.001$ vs. SAMR1 of the same age). All experiments were performed in triplicate. $\mathbf{d}$, e Representative scanned images of cochlear surface preparations from the middle turn of the cochleae of SAMR1 (d) and SAMP8 (e) mice

considered mainly due to age and independent of the strain of mouse. In contrast, a positive or negative shift indicated a correlation between molecular event and the phenotype of SAMP8 (i.e., accelerated hearing loss).

The SAMP8 strain displayed a deficit in antioxidant proteins $\mathrm{Nfr} 2$ and SOD2 and an excess of the prooxidant molecule $\mathrm{p} 66^{\mathrm{Shc}}$ at all ages. The levels of prooxidant molecules $\mathrm{p} 66^{\mathrm{Shc}}$ and $\mathrm{p}-\mathrm{p} 66^{\mathrm{Shc}}$ increased at 6 months. The samples were stained with fresh SA- $\beta$-gal solution at $\mathrm{pH}$ 6.0. Scale bar $=50 \mu \mathrm{m}$. $\mathbf{f}-\mathbf{i}$ Higher magnification images of representative organ of Corti (f, h) and spiral ganglion $(\mathbf{g}, \mathbf{i})$ derived from $\mathbf{d}$ and $\mathbf{e}$. Scale bars $=20 \mu \mathrm{m}$. $\mathbf{j}-\mathbf{o}$ Representative scanned images of transverse cryostat sections of the organ of Corti $(\mathbf{j}, \mathbf{m})$, spiral ganglion $(\mathbf{k}, \mathbf{n})$, and stria vascularis $(\mathbf{l}, \mathbf{o})$ from SAMR1 $(\mathbf{j}-\mathbf{l})$ and SAMP8 $(\mathbf{m}-\mathbf{0})$ mice at 6 months. Scale bars: $\mathbf{j}, \mathbf{k}, \mathbf{m}, \mathbf{n}=10 \mu \mathrm{m} ; \mathbf{l}, \mathbf{o}=25 \mu \mathrm{m}$. Note that SA- $\beta$-gal (blue)stained cells are mostly present in the region of spiral ganglion neurons, OHCs, and IHCs of SAMP8 mice (asterisks in $\mathbf{h}, \mathbf{i}, \mathbf{m}, \mathbf{n}$ ). SG, spiral ganglion; DCs, Deiters cells; PCs, pillar cells; sv, stria vascularis; sl, spiral ligament

concomitantly with the degradation of hearing in SAMP8, while the deficit in antioxidants remained relatively stable until 6 months of age (Fig. 8d). The differences between the strains in terms of levels of the antioxidant molecules Nrf2 and SOD2 decreased at 12 months of age (Fig. 8d), probably due to the age-related repression of these molecules in both strains. While both strains displayed comparable levels of DDR proteins ( $\mathrm{p}-\mathrm{Ch} 2$, 

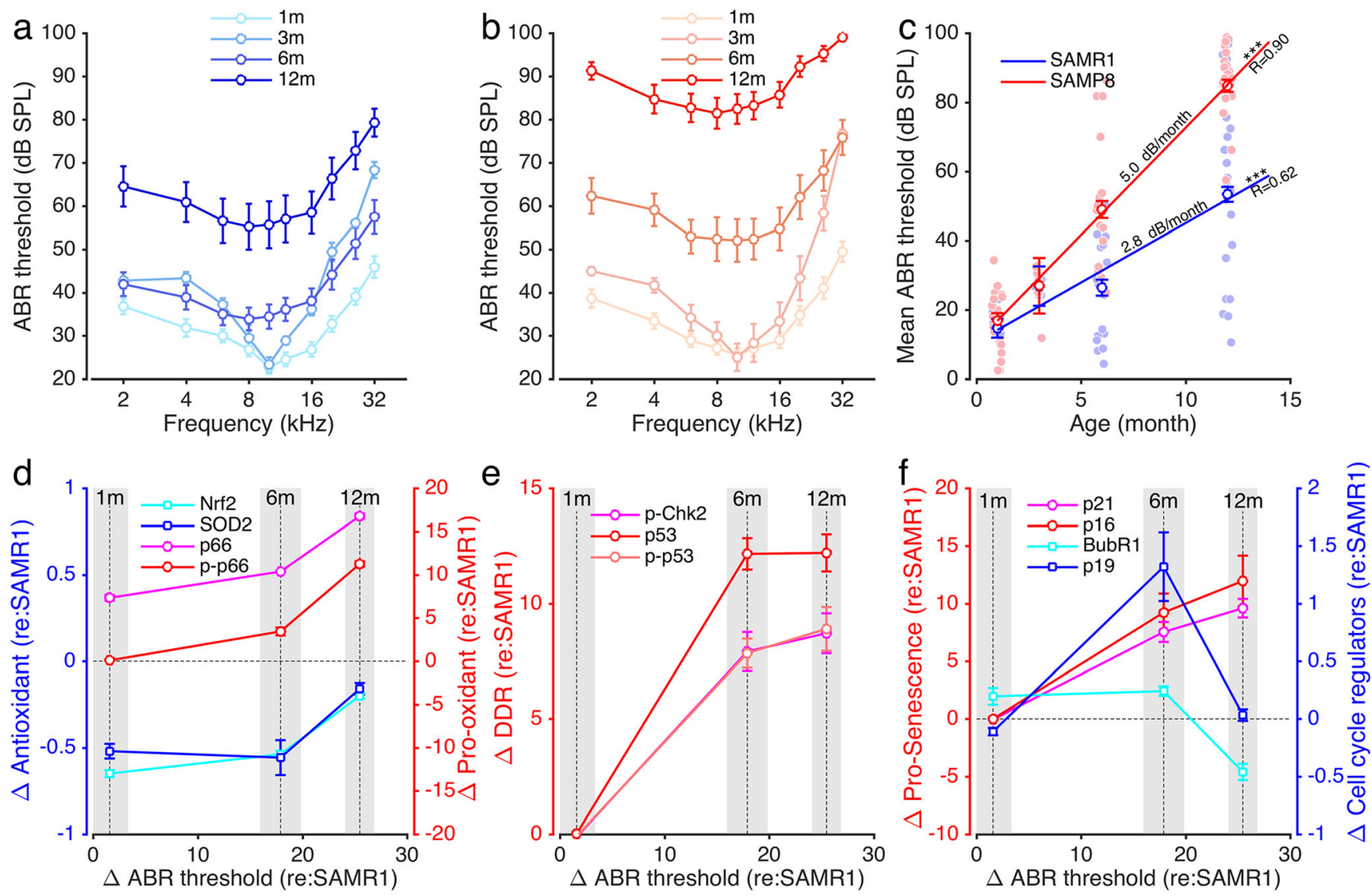

Fig. 8 Correlation between molecular events and the hearing loss. a, b Age-related ABR thresholds in SAMR1 (blue plot) (a) and in SAMP8 mice (red plot) (b) at 1, 3, 6, and 12 months ( $n=14$ animals per age and per strain). Data are expressed as mean \pm SEM. Note the severe elevation in threshold in the SAMP8 mice. $\mathbf{c}$ The mean ABR threshold from 2 to $32 \mathrm{kHz}$ derived from $\mathbf{a}$ and $\mathbf{b}$. The mean ABR thresholds for each mouse and each time point were calculated for both strains. These values were then used to perform a linear regression allowing the measurement of threshold elevation per month and the calculus of Pearson correlation coefficient. $\mathbf{d}-\mathbf{f}$ Time course of hearing loss relating to protein changes in the SAMP8 mice. The $X$-axis represents the mean difference $(\Delta)$ in ABR thresholds between SAMP8 and SAMR1 mice, and the gray area represents the SEM of these differences. The left $Y$-axis in $\mathbf{d}$ represents the

p53, p-p53) at 1 month, only SAMP8 mice thereafter showed a dramatic increase in levels to reach a plateau at 6 months (Fig. 8e). Finally, prosenescence proteins (p21, p16) increased continually with age in SAMP8 mice (Fig. 8f). By contrast, the mitotic checkpoint protein BubR1 and the cell cycle regulator p19 remained close to zero, except at 6 months where p19 had increased before falling back to zero at 12 months with a net result of no significant difference between strains at 12 months (Fig. 8f).

Collectively, these in vivo data support our in vitro results indicating that an early increase in the level of ROS triggers the activation of DNA damage responses and premature occurrence of senescence-like state in postmitotic cochlear cells and an accelerated hearing loss in SAMP8 mice. delta $(\Delta)$ in mean quantities of antioxidants (Nrf2, light blue plot and SOD2 blue plot) observed in SAMP8 mice relative to in SAMR1 mice. The right $Y$-axis in $\mathbf{d}$ represents the delta $(\Delta)$ in mean quantities of prooxidants (p66 ${ }^{\text {Shc }}$, pink plot and p-p66 ${ }^{\text {Shc }}$, red plot) observed in SAMP8 mice relative to that in SAMR1 mice. The left $Y$-axis in $\mathbf{e}$ and $\mathbf{f}$ represents the delta $(\Delta)$ in mean quantities of DNA damage response proteins (pChk2, pink plot; p53, red plot; and p-p53, light red plot in e) and of senescence markers ( $\mathrm{p} 21$, pink plot and $\mathrm{p} 16$, red plot, in $\mathbf{f}$ ). The right $Y$ axis in $\mathbf{f}$ represents the delta $(\Delta)$ in mean quantities of the mitotic checkpoint protein BubR1 (light blue plot in $\mathbf{f}$ ) and of the cell cycle regulator p19 (blue plot in $\mathbf{f}$ ) observed in SAMP8 mice relative to that in SAMR1 mice. The mean quantities of proteins were derived from Figs. 6 and 7

\section{EUK-207 Slows Down Age-Related Hearing Loss in SAMP8 Mice}

With a view to developing pharmacological therapies in vivo, we began treatment of groups of SAMP8 mice from 6 months of age with either EUK-207 dissolved in mannitol or with mannitol alone as a control, delivered by subcutaneously implanted osmotic pumps (see "Material and Methods" section). In contrast with mannitol-treated control SAMP8 mice, 2- and 3-month treatments with EUK-207 significantly prevented the age-related ABR threshold increase (Fig. 9a, b) (2 months: F1:13 $=11, P=0.006,3$ months: F1:15 = 14.4, $P=0.002$ ). The mean thresholds from EUK-207-treated and mannitoltreated SAMP8 mice were $55.7 \pm 3.5$ and $75.1 \pm 4.7 \mathrm{~dB}$, respectively, at the end of the 3-month treatment (Fig. 9a, b). 
Hearing protective effects of EUK-207 in SAMP8
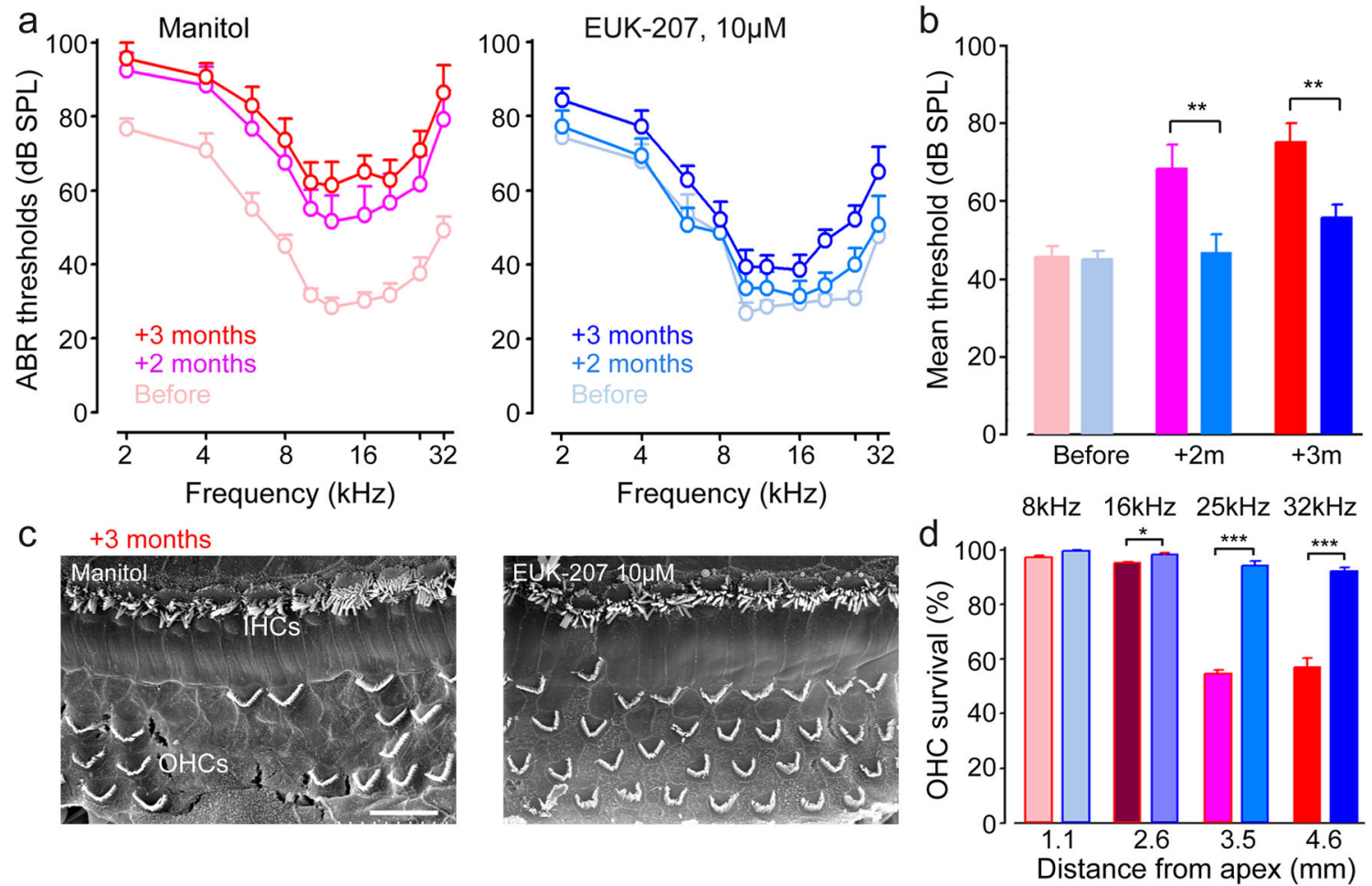

Fig. 9 Pharmacological mitigation of ROS prevents loss of hearing and hair cells in adult mice. a ABR thresholds recorded before (pale red plot) and after 2 months (pink plot) and 3 months (red plot) of mannitol treatment, or before (pale blue plot) and after 2 months (azure plot) and 3 months (blue plot) of EUK-207 treatment. b Mean ABR threshold from 2 to $32 \mathrm{kHz}$ derived from a. Data are expressed as mean $\pm \mathrm{SEM}(n=10$ per group). One-way ANOVA test was followed by post hoc Tukey's test $(* * P \leq 0.006, * * * P \leq 0.001$ vs. mannitol). c Representative scanning electron microscopy micrographs showing the basal regions of cochleae

Consistent with this finding, hair cell counting using scanning electron microscopy at the end of 3 months of treatment showed greater OHC survival in the basal region of EUK207-treated mice $(16 \mathrm{kHz}$ region: $\mathrm{F} 1: 9=7.2, P=0.028$; $25 \mathrm{kHz}: \mathrm{F} 1: 9=657.6, P<0.001 ; 32 \mathrm{kHz}: \mathrm{F} 1: 10=67.6$, $P<0.001$, Fig. 9c, d). OHC survival rates in EUK-207treated mice and mannitol-treated mice were $92.2 \pm 1.3$ and $57.12 \pm 3.44 \%$, respectively, at a frequency of $32 \mathrm{kHz}$ (Fig. $9 \mathrm{c}$, d). Altogether, these results indicate that the mitigation of excessive ROS with EUK-207 prevented accelerated agerelated hearing loss and sensory hair cell loss in SAMP8 mice.

\section{Discussion}

ARHL is the third most prevalent chronic medical condition affecting older adults [1]. Although the etiology of ARHL remains unclear, oxidative stress is proposed as one of the most important risk factors [4, 6]. Consistent with the results obtained from other cell types [30,31], cochlear sensory hair from mannitol-treated and EUK-207-treated SAMP8 mice after 3 months of treatment. Scale bar $=15 \mu \mathrm{m}$. d Cytocochleograms representing the percentage of surviving hair cells in four cochlear regions located at 1.1, 2.6, 3.5, or $4.1 \mathrm{~mm}$ from the cochlear apex from mannitol-treated (red bars) and EUK-207-treated (blue bars) SAMP8 mice ( $n=7$ per group). Data are expressed as mean \pm SEM. One-way ANOVA test was followed by post hoc Tukey's test $(* P \leq 0.028, * * * P \leq 0.001$ vs. mannitol-treated group)

cells displayed dose-dependent cytotoxic effects in cochlear explants exposed to $\mathrm{H}_{2} \mathrm{O}_{2}$. In order to examine the potential ROS-related mechanisms leading to cochlear aging, we set the level of ROS to resemble as closely as possible the in vivo conditions. Even at such low concentrations, $\mathrm{H}_{2} \mathrm{O}_{2}$ led to oxidative stress-related events in cochlear tissues 3 days after exposure. Considering the common link between oxidative stress and autophagy [34], we assessed autophagy induction by monitoring autophagosome formation and autophagic flux. As suspected, $\mathrm{H}_{2} \mathrm{O}_{2}$-induced oxidative stress initiated autophagy, as illustrated by the activation or increased expression of several autophagy-related proteins, such as Beclin 1, LC3-II, Rab7, and p62. The increased level of the autophagic substrate p62 in particular indicated an impaired autophagic flux [49]. Collectively, these results demonstrate that at low concentrations (below $\mathrm{EC}_{50}$ ), $\mathrm{H}_{2} \mathrm{O}_{2}$ can induce oxidative stress and trigger an impaired autophagic response, and they thereby validate our in vitro model of oxidative stress.

Unlike the necrosis or apoptosis observed in cells subjected to cytotoxic doses of $\mathrm{H}_{2} \mathrm{O}_{2}$, we have here discovered that 
exposure to low concentrations of $\mathrm{H}_{2} \mathrm{O}_{2}$ slightly alters cochlear cell viability within 3 days after exposure but importantly induces DNA damage, mainly in sensory hair cells. These results are consistent with our previous study in which genotoxic stress was induced by cisplatin, a DNA-damaging anticancer drug [12]. In the present study, $\mathrm{H}_{2} \mathrm{O}_{2}$ exposure induced DNA damage responses within cochlear cells, as shown by significant increases in DDB2, a protein involved in nucleotide excision repair [43], p-Chk2, and p53. Depending on the severity of the DNA damage, the cell microenvironment, and the cell type, activated p53 can orchestrate different cellular outcomes such as repair of DNA damage, apoptosis, or senescence [50].

DNA damage and DDR are known to be involved in the induction of replicative senescence and DNA damaging agent-induced premature senescence in cycling cells $[51,52]$. Here, we have demonstrated for the first time that the ROS-induced DDR coincided with the premature occurrence of senescence-like features in postmitotic cochlear cells, as shown by increased levels of $\mathrm{p} 21$, a substrate of $\mathrm{p} 53$, and a necessary signal transducer between DDR and senescence in neurons [53]. Consistent with the increase in $\mathrm{p} 21, \mathrm{H}_{2} \mathrm{O}_{2}$-exposed cochleae displayed high levels of p38 and phospho-p38. These latter two proteins can be activated by $\mathrm{p} 21$ and may be implicated in senescence-associated secretory phenotypes [54]. Together with increased activity of SA- $\beta$-gal following $\mathrm{H}_{2} \mathrm{O}_{2}$ exposure, our results indicate that the activation of the p53-p21 pathway might mediate the low concentration $\mathrm{H}_{2} \mathrm{O}_{2}$-induced senescence-like phenotype in postmitotic cochlear cells in vitro. To shed more light on these postmitotic cochlear cell senescence-like phenotypes, we quantified the levels of p16, named also $\mathrm{p} 16^{\mathrm{INK} 4 \mathrm{~A}}$, which can be induced independently of DDR and p53. Above a certain threshold, p16 blocks G1-S progression within cycling cells [55] and may act as an effector of senescence in cultured cells [56]. However, our $\mathrm{H}_{2} \mathrm{O}_{2}$-exposed cochleae exhibited no significantly increased levels of p16 arguing against the engagement of the p16 pathway in our in vitro conditions.

We also assessed the level of the mitotic checkpoint protein BubR1, the level of which decreases with age in various mouse tissues [57]. BubR1 insufficiency is associated with the occurrence of multiple progeroid and aging-associated phenotypes in mice [58] and in children with mosaic variegated aneuploidy syndrome [59]. Consistent with these reports, we found a significantly decreased expression of BubR1 after $\mathrm{H}_{2} \mathrm{O}_{2}$ challenge suggesting its implication in ROS-induced premature cochlear cell senescence-like phenotypes. We also found a significantly decreased expression of the cell cycle regulator p19 in $\mathrm{H}_{2} \mathrm{O}_{2}$-exposed cochleae. This protein likely plays a role in the attenuation of senescence and aging in BubR1-insufficient mice [60], yet the precise relationship between its decreased level and increased cochlear cell senescence-like phenotypes after ROS challenge requires further in-depth investigation.

To probe the impact of ROS mitigation on $\mathrm{H}_{2} \mathrm{O}_{2}$-induced DNA damage and senescence-like phenotypes, we tested a synthetic SOD/catalase mimetic, EUK-207. This molecule possesses both SOD and catalase activity and scavenges ROS generated in the cytoplasm or organelles, including the mitochondria [17]. In addition, EUK-207 suppresses oxidative modifications of proteins, lipids, and nucleic acids [61]. Here, we found that cochleae treated with EUK-207, alone or in combination with $\mathrm{H}_{2} \mathrm{O}_{2}$, displayed increased levels of FOXO3a and Nrf2. These two transcription factors have been shown to positively regulate cellular resistance to oxidative stress [47, 62]. Increasing their levels of expression would be expected therefore to account for the observed protective effect of EUK-207 against $\mathrm{H}_{2} \mathrm{O}_{2}$-induced DNA damage and senescence-like phenotype in cochlear cells in culture.

To extend these in vitro data to the system level, we used SAMP8 mice. This strain of mouse develops a premature ARHL and early onset cochlear cell degeneration [4]. Here, we showed that, compared to control, SAMP8 cochleae displayed an early increased oxidative stress (1 month of age), highlighted by significantly lower levels of both Nrf2, a main regulator of cellular resistance to oxidants, and the antioxidant enzyme SOD2, concomitant with a large increase in the levels of $\mathrm{p} 66^{\text {Shc }}$ and its phosphorylated form. These two latter proteins are involved in downregulating the synthesis of antioxidant enzymes and the generation of ROS in the mitochondria [63]. These in vivo data indicate that the events related to oxidative stress occur early (1 month of age), before the onset of hearing loss in SAMP8 mice (3 months) [4]. Here, we also found significantly higher levels of phosphorylated Beclin 1, Rab7, and p62 in SAMP8 mice during aging compared with SAMR1. Together with our previous study demonstrating the upregulation of LC3-II with concomitant accumulation of lipofuscin in SAMP8 mouse cochleae, we suggest an increased autophagy with impaired and/or insufficient capacity for autophagy flux in SAMP8 mice. These results are consistent with some recent studies showing that autophagy plays an important role in maintaining adult hearing in response to auditory stress or during aging. Indeed, activation of autophagy by rapamycin diminished noise- [64] or cisplatin-induced [65] hair cell and hearing loss. Moreover, the weaker autophagy gene expression in 1-year-old cochleae of $\mathrm{Igfl}^{-/-}$mice coincides with age-related hearing loss [66, 67].

Consistent with our in vitro results, the SAMP8 mice displayed activation of the Chk2-p53 pathway from 6 months of age. From the same age, they also displayed similar senescence signatures, characterized by decreased levels of BubR1 and increased levels of p21 and p16, together with increased activity of SA- $\beta$-gal in the region of spiral ganglion neurons, 
OHCs, and IHCs of SAMP8 mice. These discoveries are consistent with recent studies in which activation of DNA damage responses and the appearance of certain cell senescence markers were implicated in postmitotic neuron senescence $[68,69]$. Based on the significant correlation between early increased oxidative stress together with later accumulation of DDR and senescence-like features, and severe hearing loss in SAMP8 mice, we suggest that oxidative stress may be one of the main culprits behind age-related cochlear cell degeneration and auditory function decline.

Having established the causal relationship between ROS and age-related cochlear cell degeneration, we set out to test the efficiency of systemically administering EUK-207 to mitigate the pathological effects of uncontrolled ROS production on hearing function. Our results reveal that systemic treatment with EUK-207 effectively prevented or slowed down ARHL in SAMP8 mice. These results are consistent with previous studies showing successful suppression of age-related cognitive impairment in mice with EUK-207 [15, 16]. They also represent a proof-of-concept that pharmacological scavenging of superoxide and hydrogen peroxide can mitigate ARHL in SAMP8 mice. They thereby provide a strong rationale for the clinical development of EUK-207 for use in the prevention or slowing down of ARHL in humans.

\section{Conclusion}

The in vitro and in vivo data presented here provide evidence that (i) ROS is one of the main culprits behind age-related sensory hair cell degeneration, (ii) ROS-induced DDR driving senescence-like features may account for premature cochlear aging, and (iii) pharmacological scavenging of superoxide and hydrogen peroxide can mitigate ARHL in SAMP8 mice.

\begin{abstract}
Acknowledgments The authors would like to thank Dr. Jérôme Bourien and Adrien Caplot for statistical analyses and Dr. Alexandre Pattyn, Dr. Régis Nouvian, and Dr. Patrick Carroll for helpful discussions. All confocal and electron-microscopic analyses were performed at the Montpellier RIO Imaging-INM core facility. The manuscript has been revised by an independent scientific English language editing service (Angloscribe).
\end{abstract}

Funding Information This work was supported by the Fondation de l'Avenir (Et2-675) and the Fondation Gueules Cassées.

\section{Compliance with Ethical Standards}

Experiments were carried out in accordance with the animal welfare guidelines 2010/63/EC of the European Communities Council Directive and French Ethical Committee (agreements 00447.01), regarding the care and use of animals for experimental procedures.

Conflict of Interest The authors declare that they have no conflicts of interest.
Abbreviations $A R H L$, age-related hearing loss; Cat, catalase; $D D B 2$, DNA damage-binding protein 2; DDR, DNA damage response; $I H C s$, inner hair cells; $\mathrm{Nrf} 2$, nuclear factor erythroid 2-related factor 2; $\mathrm{OHCs}$, outer hair cells; $p$-Chk1, checkpoint kinase $1 ; p$-Chk2, checkpoint kinase 2; ROS, reactive oxygen species; $S A M P 8$, senescence-accelerated prone 8 mice; $S A M R 1$, senescence-accelerated resistant 1 mice; $S O D$, superoxide dismutase

Open Access This article is distributed under the terms of the Creative Commons Attribution 4.0 International License (http:// creativecommons.org/licenses/by/4.0/), which permits unrestricted use, distribution, and reproduction in any medium, provided you give appropriate credit to the original author(s) and the source, provide a link to the Creative Commons license, and indicate if changes were made.

Publisher's Note Springer Nature remains neutral with regard to jurisdictional claims in published maps and institutional affiliations.

\section{References}

1. Lethbridge-Cejku M, Schiller JS, Bernadel L (2004) Summary health statistics for U.S. adults: National Health Interview Survey, 2002. Vital Health Stat Series 10, Data from the National Health Survey (222):1-151.

2. Jayakody DMP, Friedland PL, Martins RN, Sohrabi HR (2018) Impact of aging on the auditory system and related cognitive functions: a narrative review. Front Neurosci 12:125. https://doi.org/10. 3389/fnins.2018.00125

3. Han C, Someya S (2013) Mouse models of age-related mitochondrial neurosensory hearing loss. Mol Cell Neurosci 55:95-100. https://doi.org/10.1016/j.mcn.2012.07.004

4. Menardo J, Tang Y, Ladrech S, Lenoir M, Casas F, Michel C, Bourien J, Ruel J et al (2012) Oxidative stress, inflammation, and autophagic stress as the key mechanisms of premature age-related hearing loss in SAMP8 mouse cochlea. Antioxid Redox Signal 16(3):263-274. https://doi.org/10.1089/ars.2011.4037

5. Jiang H, Talaska AE, Schacht J, Sha SH (2007) Oxidative imbalance in the aging inner ear. Neurobiol Aging 28(10):1605-1612. https://doi.org/10.1016/j.neurobiolaging.2006.06.025

6. Someya S, Xu J, Kondo K, Ding D, Salvi RJ, Yamasoba T, Rabinovitch PS, Weindruch R et al (2009) Age-related hearing loss in $\mathrm{C} 57 \mathrm{BL} / 6 \mathrm{~J}$ mice is mediated by Bak-dependent mitochondrial apoptosis. Proc Natl Acad Sci U S A 106(46):19432-19,437. https://doi.org/10.1073/pnas.0908786106

7. Keithley EM, Canto C, Zheng QY, Wang X, Fischel-Ghodsian N, Johnson KR (2005) $\mathrm{Cu} / \mathrm{Zn}$ superoxide dismutase and age-related hearing loss. Hear Res 209(1-2):76-85. https://doi.org/10.1016/j. heares.2005.06.009

8. Ying YL, Balaban CD (2009) Regional distribution of manganese superoxide dismutase 2 (Mn SOD2) expression in rodent and primate spiral ganglion cells. Hear Res 253(1-2):116-124. https://doi. org/10.1016/j.heares.2009.04.006

9. Lasisi AO, Fehintola FA (2011) Correlation between plasma levels of radical scavengers and hearing threshold among elderly subjects with age-related hearing loss. Acta Otolaryngol 131(11):11601164. https://doi.org/10.3109/00016489.2010.549840

10. Mantha AK, Sarkar B, Tell G (2014) A short review on the implications of base excision repair pathway for neurons: relevance to neurodegenerative diseases. Mitochondrion 16:38-49. https://doi. org/10.1016/j.mito.2013.10.007

11. Breen AP, Murphy JA (1995) Reactions of oxyl radicals with DNA. Free Radic Biol Med 18(6):1033-1077 
12. Benkafadar N, Menardo J, Bourien J, Nouvian R, Francois F, Decaudin D, Maiorano D, Puel JL et al (2017) Reversible p53 inhibition prevents cisplatin ototoxicity without blocking chemotherapeutic efficacy. EMBO Mol Med 9(1):7-26. https://doi.org/10. 15252/emmm.201606230

13. Doctrow SR, Huffman K, Marcus CB, Tocco G, Malfroy E, Adinolfi CA, Kruk H, Baker K et al (2002) Salen-manganese complexes as catalytic scavengers of hydrogen peroxide and cytoprotective agents: structure-activity relationship studies. J Med Chem 45(20):4549-4558

14. Liesa M, Luptak I, Qin F, Hyde BB, Sahin E, Siwik DA, Zhu Z, Pimentel DR et al (2011) Mitochondrial transporter ATP binding cassette mitochondrial erythroid is a novel gene required for cardiac recovery after ischemia/reperfusion. Circulation 124(7):806-813. https://doi.org/10.1161/CIRCULATIONAHA.110.003418

15. Clausen A, Doctrow S, Baudry M (2010) Prevention of cognitive deficits and brain oxidative stress with superoxide dismutase/ catalase mimetics in aged mice. Neurobiol Aging 31(3):425-433. https://doi.org/10.1016/j.neurobiolaging.2008.05.009

16. Liu R, Liu IY, Bi X, Thompson RF, Doctrow SR, Malfroy B, Baudry M (2003) Reversal of age-related learning deficits and brain oxidative stress in mice with superoxide dismutase/catalase mimetics. Proc Natl Acad Sci U S A 100(14):8526-8531. https:// doi.org/10.1073/pnas.1332809100

17. Raber J, Davis MJ, Pfankuch T, Rosenthal R, Doctrow SR, Moulder JE (2017) Mitigating effect of EUK-207 on radiationinduced cognitive impairments. Behav Brain Res 320:457-463. https://doi.org/10.1016/j.bbr.2016.10.038

18. Takeda T, Hosokawa M, Takeshita S, Irino M, Higuchi K, Matsushita T, Tomita Y, Yasuhira K et al (1981) A new murine model of accelerated senescence. Mech Ageing Dev 17(2):183194

19. Flood JF, Morley JE (1998) Learning and memory in the SAMP8 mouse. Neurosci Biobehav Rev 22(1):1-20

20. Wang J, Van De Water TR, Bonny C, de Ribaupierre F, Puel JL, Zine A (2003) A peptide inhibitor of c-Jun N-terminal kinase protects against both aminoglycoside and acoustic trauma-induced auditory hair cell death and hearing loss. J Neurosci 23(24):85968607

21. Pronsato L, Milanesi L (2016) Effect of testosterone on the regulation of p53 and p66Shc during oxidative stress damage in $\mathrm{C} 2 \mathrm{C} 12$ cells. Steroids 106:41-54. https://doi.org/10.1016/j.steroids.2015. 12.007

22. Baek SM, Yu SY, Son Y, Hong HS (2016) Substance P promotes the recovery of oxidative stress-damaged retinal pigmented epithelial cells by modulating Akt/GSK-3beta signaling. Mol Vis 22: 1015-1023

23. Marklund S (1976) Spectrophotometric study of spontaneous disproportionation of superoxide anion radical and sensitive direct assay for superoxide dismutase. J Biol Chem 251(23):7504-7507

24. Sunderman FW Jr, Marzouk A, Hopfer SM, Zaharia O, Reid MC (1985) Increased lipid peroxidation in tissues of nickel chloridetreated rats. Ann Clin Lab Sci 15(3):229-236

25. Ladrech S, Wang J, Simonneau L, Puel JL, Lenoir M (2007) Macrophage contribution to the response of the rat organ of Corti to amikacin. J Neurosci Res 85(9):1970-1979. https://doi.org/10. 1002/jnr.21335

26. Oh GS, Kim HJ, Choi JH, Shen A, Kim CH, Kim SJ, Shin SR, Hong SH et al (2011) Activation of lipopolysaccharide-TLR4 signaling accelerates the ototoxic potential of cisplatin in mice. $\mathrm{J}$ Immunol 186(2):1140-1150. https://doi.org/10.4049/jimmunol. 1002183

27. Muller M, von Hunerbein K, Hoidis S, Smolders JW (2005) A physiological place-frequency map of the cochlea in the CBA/J mouse. Hear Res 202(1-2):63-73. https://doi.org/10.1016/j. heares.2004.08.011
28. Wang J, Ladrech S, Pujol R, Brabet P, Van De Water TR, Puel JL (2004) Caspase inhibitors, but not c-Jun NH2-terminal kinase inhibitor treatment, prevent cisplatin-induced hearing loss. Cancer Res 64(24):9217-9224. https://doi.org/10.1158/0008-5472.CAN$04-1581$

29. Wang J, Lloyd Faulconbridge RV, Fetoni A, Guitton MJ, Pujol R, Puel JL (2003) Local application of sodium thiosulfate prevents cisplatin-induced hearing loss in the guinea pig. Neuropharmacology 45(3):380-393

30. Spector A (1995) Oxidative stress-induced cataract: mechanism of action. FASEB J 9(12):1173-1182

31. Zheng Y, Liu Y, Ge J, Wang X, Liu L, Bu Z, Liu P (2010) Resveratrol protects human lens epithelial cells against $\mathrm{H} 2 \mathrm{O} 2$ induced oxidative stress by increasing catalase, SOD-1, and HO-1 expression. Mol Vis 16:1467-1474

32. Dufour E, Larsson NG (2004) Understanding aging: revealing order out of chaos. Biochim Biophys Acta 1658(1-2):122-132. https://doi.org/10.1016/j.bbabio.2004.04.020

33. Lebiedzinska M, Duszynski J, Rizzuto R, Pinton P, Wieckowski MR (2009) Age-related changes in levels of p66Shc and serine 36-phosphorylated p66Shc in organs and mouse tissues. Arch Biochem Biophys 486(1):73-80. https://doi.org/10.1016/j.abb. 2009.03.007

34. Filomeni G, De Zio D, Cecconi F (2015) Oxidative stress and autophagy: the clash between damage and metabolic needs. Cell Death Differ 22(3):377-388. https://doi.org/10.1038/cdd.2014.150

35. Cao Y, Klionsky DJ (2007) Physiological functions of Atg6/Beclin 1: a unique autophagy-related protein. Cell Res 17(10):839-849. https://doi.org/10.1038/cr.2007.78

36. Jager S, Bucci C, Tanida I, Ueno T, Kominami E, Saftig P, Eskelinen EL (2004) Role for Rab7 in maturation of late autophagic vacuoles. J Cell Sci 117(Pt 20):4837-4848. https://doi.org/10. $1242 /$ jcs. 01370

37. Rogakou EP, Pilch DR, Orr AH, Ivanova VS, Bonner WM (1998) DNA double-stranded breaks induce histone H2AX phosphorylation on serine 139. J Biol Chem 273(10):5858-5868

38. Schultz LB, Chehab NH, Malikzay A, Halazonetis TD (2000) p53 binding protein $1(53 \mathrm{BP} 1)$ is an early participant in the cellular response to DNA double-strand breaks. J Cell Biol 151(7):13811390

39. Shiloh Y (2003) ATM and related protein kinases: safeguarding genome integrity. Nat Rev Cancer 3(3):155-168. https://doi.org/ $10.1038 / \mathrm{nrc} 1011$

40. Ou HL, Schumacher B (2018) DNA damage responses and p53 in the aging process. Blood 131(5):488-495. https://doi.org/10.1182/ blood-2017-07-746,396

41. Di Micco R, Cicalese A, Fumagalli M, Dobreva M, Verrecchia A, Pelicci PG, di Fagagna F (2008) DNA damage response activation in mouse embryonic fibroblasts undergoing replicative senescence and following spontaneous immortalization. Cell Cycle 7(22): 3601-3606

42. Shiloh Y (2006) The ATM-mediated DNA-damage response: taking shape. Trends Biochem Sci 31(7):402-410. https://doi.org/10. 1016/j.tibs.2006.05.004

43. Puumalainen MR, Lessel D, Ruthemann P, Kaczmarek N, Bachmann K, Ramadan K, Naegeli H (2014) Chromatin retention of DNA damage sensors DDB2 and XPC through loss of p97 segregase causes genotoxicity. Nat Commun 5:3695. https://doi. org/10.1038/ncomms4695

44. Brancho D, Tanaka N, Jaeschke A, Ventura JJ, Kelkar N, Tanaka Y, Kyuuma M, Takeshita T et al (2003) Mechanism of p38 MAP kinase activation in vivo. Genes Dev 17(16):1969-1978. https:// doi.org/10.1101/gad.1107303

45. Bernardes de Jesus B, Blasco MA (2012) Assessing cell and organ senescence biomarkers. Circ Res 111(1):97-109. https://doi.org/10. 1161/CIRCRESAHA.111.247866 
46. Rosenthal RA, Fish B, Hill RP, Huffman KD, Lazarova Z, Mahmood J, Medhora M, Molthen R et al (2011) Salen Mn complexes mitigate radiation injury in normal tissues. Anti Cancer Agents Med Chem 11(4):359-372

47. Burgering BM, Medema RH (2003) Decisions on life and death: FOXO Forkhead transcription factors are in command when $\mathrm{PKB} /$ Akt is off duty. J Leukoc Biol 73(6):689-701

48. Dinkova-Kostova AT, Abramov AY (2015) The emerging role of Nrf2 in mitochondrial function. Free Radic Biol Med 88(Pt B): 179 188. https://doi.org/10.1016/j.freeradbiomed.2015.04.036

49. Liu X, Ling M, Chen C, Luo F, Yang P, Wang D, Chen X, Xu H et al (2017) Impaired autophagic flux and p62-mediated EMT are involved in arsenite-induced transformation of L-02 cells. Toxicol Appl Pharmacol 334:75-87. https://doi.org/10.1016/j.taap.2017. 09.004

50. Fumagalli M, Rossiello F, Mondello C, d'Adda di Fagagna F (2014) Stable cellular senescence is associated with persistent DDR activation. PLoS One 9(10):e110969. https://doi.org/10. 1371/journal.pone.0110969

51. Bodnar AG, Ouellette M, Frolkis M, Holt SE, Chiu CP, Morin GB, Harley CB, Shay JW et al (1998) Extension of life-span by introduction of telomerase into normal human cells. Science 279(5349): 349-352

52. Robles SJ, Adami GR (1998) Agents that cause DNA double strand breaks lead to p16INK4a enrichment and the premature senescence of normal fibroblasts. Oncogene 16(9):1113-1123. https://doi.org/ 10.1038/sj.onc.1201862

53. Piechota M, Sunderland P, Wysocka A, Nalberczak M, Sliwinska MA, Radwanska K, Sikora E (2016) Is senescence-associated betagalactosidase a marker of neuronal senescence? Oncotarget 7(49): 81099-81109. https://doi.org/10.18632/oncotarget.12752

54. Aoshiba K, Tsuji T, Kameyama S, Itoh M, Semba S, Yamaguchi K, Nakamura H (2013) Senescence-associated secretory phenotype in a mouse model of bleomycin-induced lung injury. Exp Toxicol Pathol 65(7-8):1053-1062. https://doi.org/10.1016/j.etp.2013.04. 001

55. Collado M, Blasco MA, Serrano M (2007) Cellular senescence in cancer and aging. Cell 130(2):223-233. https://doi.org/10.1016/j. cell.2007.07.003

56. Kim WY, Sharpless NE (2006) The regulation of INK4/ARF in cancer and aging. Cell 127(2):265-275. https://doi.org/10.1016/j. cell.2006.10.003

57. Baker DJ, Dawlaty MM, Wijshake T, Jeganathan KB, Malureanu L, van Ree JH, Crespo-Diaz R, Reyes S et al (2013) Increased expression of BubR1 protects against aneuploidy and cancer and extends healthy lifespan. Nat Cell Biol 15(1):96-102. https://doi. org/10.1038/ncb2643

58. Baker DJ, Jeganathan KB, Cameron JD, Thompson M, Juneja S, Kopecka A, Kumar R, Jenkins RB et al (2004) BubR1 insufficiency causes early onset of aging-associated phenotypes and infertility in mice. Nat Genet 36(7):744-749. https://doi.org/10.1038/ng1382

59. Matsuura $\mathrm{S}$, Matsumoto $\mathrm{Y}$, Morishima $\mathrm{K}$, Izumi $\mathrm{H}$, Matsumoto $\mathrm{H}$, Ito E, Tsutsui K, Kobayashi J et al (2006) Monoallelic BUB1B mutations and defective mitotic-spindle checkpoint in seven families with premature chromatid separation (PCS) syndrome. Am J Med Genet A 140(4):358-367. https://doi.org/10.1002/ajmg.a. 31069

60. Baker DJ, Perez-Terzic C, Jin F, Pitel KS, Niederlander NJ, Jeganathan K, Yamada S, Reyes S et al (2008) Opposing roles for p16Ink4a and p19Arf in senescence and ageing caused by BubR1 insufficiency. Nat Cell Biol 10(7):825-836. https://doi.org/10. 1038/ncb1744

61. Doctrow SR, Lopez A, Schock AM, Duncan NE, Jourdan MM, Olasz EB, Moulder JE, Fish BL et al (2013) A synthetic superoxide dismutase/catalase mimetic EUK-207 mitigates radiation dermatitis and promotes wound healing in irradiated rat skin. J Invest Dermatol 133(4):1088-1096. https://doi.org/10.1038/jid.2012.410

62. Zhang X, Chen X, Song H, Chen HZ, Rovin BH (2005) Activation of the Nrf2/antioxidant response pathway increases IL- 8 expression. Eur J Immunol 35(11):3258-3267. https://doi.org/10.1002/ eji.200526116

63. Galimov ER (2010) The role of p66shc in oxidative stress and apoptosis. Acta Nat 2(4):44-51

64. Yuan H, Wang X, Hill K, Chen J, Lemasters J, Yang SM, Sha SH (2015) Autophagy attenuates noise-induced hearing loss by reducing oxidative stress. Antioxid Redox Signal 22(15):1308-1324. https://doi.org/10.1089/ars.2014.6004

65. Fang B, Xiao H (2014) Rapamycin alleviates cisplatin-induced ototoxicity in vivo. Biochem Biophys Res Commun 448(4):443-447. https://doi.org/10.1016/j.bbrc.2014.04.123

66. Varela-Nieto I, Murillo-Cuesta S, Rodriguez-de la Rosa L, Lassatetta L, Contreras J (2013) IGF-I deficiency and hearing loss: molecular clues and clinical implications. Pediatr Endocrinol Rev 10(4):460-472

67. de Iriarte Rodriguez R, Pulido S, Rodriguez-de la Rosa L, Magarinos M, Varela-Nieto I (2015) Age-regulated function of autophagy in the mouse inner ear. Hear Res 330(Pt A):39-50. https://doi.org/10.1016/j.heares.2015.07.020

68. Jurk D, Wang C, Miwa S, Maddick M, Korolchuk V, Tsolou A, Gonos ES, Thrasivoulou C et al (2012) Postmitotic neurons develop a $\mathrm{p} 21$-dependent senescence-like phenotype driven by a DNA damage response. Aging Cell 11(6):996-1004. https://doi.org/10. $1111 / \mathrm{j} .1474-9726.2012 .00870 . x$

69. Fielder E, von Zglinicki T, Jurk D (2017) The DNA damage response in neurons: die by apoptosis or survive in a senescence-like state? J Alzheimers Dis 60(s1):S107-S131. https://doi.org/10.3233/ JAD-161221 